\title{
A review of the parasitic dinoflagellates Hematodinium species and Hematodinium-like infections in marine crustaceans
}

\author{
Grant D. Stentiford ${ }^{1, *}$, Jeffrey D. Shields ${ }^{2}$ \\ ${ }^{1}$ Centre for Environment, Fisheries and Aquaculture Science (CEFAS), Barrack Road, The Nothe, Weymouth, \\ Dorset DT4 8UB, UK \\ ${ }^{2}$ Virginia Institute of Marine Science (VIMS), The College of William and Mary, Gloucester Point, Virginia 23062, USA
}

\begin{abstract}
Parasitic dinoflagellates in the genus Hematodinium are important parasites of marine Crustacea. Outbreaks of these parasites have damaged commercial stocks of Norway lobster Nephrops norvegicus, snow crab Chionoecetes opilio, Tanner crab C. bairdi, American blue crab Callinectes sapidus, and velvet swimming crab Necora puber. Species of Hematodinium can reach high enough levels to regulate their host populations, but mortalities are also centred on the unfished juveniles and females, hosts not normally sampled by fisheries; hence impacts are often underreported. Seasonal prevalences of up to $85 \%$ occur annually in many host populations; in effect, these parasites form cryptic blooms in the water column with crabs and other crustaceans at risk of disease. We review the biology and ecology of Hematodinium spp. infections in crustaceans. Included is a comparison of the different infections, a synthesis of what is known, and an attempt to highlight fruitful areas for continued research.
\end{abstract}

KEY WORDS: Fishery $\cdot$ Crab $\cdot$ Lobster $\cdot$ Disease $\cdot$ Pathology $\cdot$ Life cycle $\cdot$ Physiology $\cdot$ Population

\section{INTRODUCTION}

The parasitic dinoflagellates in the genus Hematodinium and Hematodinium-like species (hereafter referred to as Hematodinium) have recently gained attention as pathogens of commercially important crustaceans. Several studies have described major epizootics that have damaged fisheries for snow crabs Chionoecetes opilio, blue crabs Callinectes sapidus and Norway lobsters Nephrops norvegicus. Affected hosts undergo dramatic pathological alterations to their organs, tissues and haemolymph. Such alterations have effects at several organizational levels and provide challenging problems for study. For example, at the commercial level, biochemical alterations to the meat of patently infected Tanner crabs $C$. bairdi and snow crabs causes a condition known as bitter crab disease (BCD) or bitter crab syndrome that renders them unmarketable, with a single infected crab ruining the flavor of an entire batch of processed crabs (Meyers et al. 1987, Taylor \& Khan 1995). At the population level, infections often have extremely high prevalences in juvenile and female hosts, with the potential for dramatic, but cryptic effects on host populations (Meyers et al. 1987, Wilhelm \& Mialhe 1996, Messick \& Shields 2000, Stentiford et al. 2000a, 2001b,c,d, Pestal et al. 2003, Shields et al. 2005). At the organismal level, physiological and biochemical disruptions to the muscles and other organs substantially alter the metabolism of infected hosts providing insights into the host's physiology as well as immune defences (Taylor et al. 1996, Stentiford et al. 2000a,b, 2001a,b, 2003, Shields et al. 2003). At the molecular level, much remains to be done for there are numerous questions to resolve regarding the life cycle, the use of alternate hosts, host specificity, and how these parasites move through host populations. 
We believe that Hematodinium is one of the most economically significant diseases of Crustacea and ranks among viral diseases in shrimp, and gaffkemia infection in the American lobster in terms of the impact to fisheries and host populations. As such, we present a synthetic review of Hematodinium. Included in this review is an assessment of the current taxonomic status of these parasites, appraisal of the methods used for diagnosis of infection, evaluation of the pathophysiological effect of disease, analysis of the epizootiology of disease caused by Hematodinium, with links to transmission and life history of the parasite, and finally, the potential for economic damage caused by these infections. We attempt to identify gaps in current knowledge and to highlight important directions for future research in this field.

\section{SYSTEMATIC OVERVIEW}

Parasitic dinoflagellates infect algae, protozoans, annelids, crustaceans, molluscs, salps, ascidians, rotifers, and fishes (Cachon \& Cachon 1987, Shields 1994, Coats 1999). At present, approximately 35 genera within 4 botanical orders; the Phytodiniales, Gymonodiniales, Blastodiniales, and Syndiniales, contain species that are known to be parasitic; the latter 2 orders consist entirely of parasitic taxa.

Interestingly, the dinoflagellates share certain affinities with the Ciliophora and the Sporozoa (Apicomplexa) placing them collectively in the superphylum Alveolata (Gajadhar et al. 1991). Morphologically, they all possess a trilaminar alveolate pellicle (CavalierSmith 1993) and have distinct molecular affinities (Gajadhar et al. 1991). Recently, micropores, organelles for endocytosis, were observed in the filamentous trophont (cf. vermiform plasmodium) and amoeboid trophont stages of Hematodinium parasites from Nephrops norvegicus (Appleton \& Vickerman 1996). Micropores are an important morphological feature of the Apicomplexa and are also common to the Alveolata. Nonetheless, details of mitosis are quite different between these phyla and morphologically there are few other similarities.

Systematically, the genus Hematodinium belongs in the family Syndiniceae, order Syndinida (Syndiniales to botanists). Members of the Syndinida have life cycles consisting of at least 3 phases: a multinucleate plasmodial stage, a vegetative phase (trophont, produced via merogony) and an asexual reproductive phase (sporont produced via sporogony). In the Syndinida, sporogony leads to the formation of 2 dissimilar forms of biflagellate dinospores ('swarmers') that arise from different parent infections and ensure dispersal and new infection (Cachon \& Cachon 1987). Meiosis and gamogony have not been described for members of the genus Hematodinium; the macrodinospores and microdinospores appear to be products of sporogony and have similar DNA content as other stages (Eaton et al. 1991).

Virtually all of the Syndinida are parasitic in the haemocoels of invertebrate hosts. They occur primarily as plasmodial forms that rapidly divide and grow until they undergo sporogony to produce a motile spore stage. The plasmodial stage has no chloroplasts and obtains nutrition via osmotrophy during the trophic phase, where lipid and polysaccharide inclusions suggest active feeding at the expense of the host. Sporogenesis is simple with multiplication of the nuclei, plasmodial and cytoplasmic divisions occurring to produce sporocysts, following which the biflagellate zoospores are produced and liberated (Cachon \& Cachon 1987). Four genera of syndinids are parasitic in crustaceans; Actinodinium, Trypanodinium, Syndinium and Hematodinium. Of these, Actinodinium in copepods and Trypanodinium on copepod eggs have not been well documented, while Syndinium and especially Hematodinium have been better studied (see Shields 1994 for review). Infections by $S$. turbo, $S$. corycaei and $S$. gammari have been described in copepods and amphipods where infection presumably occurs via ingestion of dinospores by the host (Manier et al. 1971).

\section{Taxonomy and systematics}

Members of the genus Hematodinium are primarily parasites of decapod crustaceans. They can be identified as dinoflagellates on the basis of their typical dinokaryon (or mesokaryon, Chatton 1920), the alveolate pellicle, the presence of naked, athecate gymnodinoid dinospores (or zoospores), and the classic form of mitosis known as dinomitosis (similar to that reported for the genus Syndinium, see Ris \& Kublai 1974). Due to their lack of distinct characteristics and their poorly understood life cycles, there are only 2 described species of Hematodinium. The type species, H. perezi, was first described from the portunid crabs Carcinus maenas and Liocarcinus depurator off Luc-sur-Mer and Roscoff, on the coast of Normandy, France, and off Banyuls-sur-Mer, on the Mediterranean coast of France (Chatton \& Poisson 1931). Unfortunately, Chatton \& Poisson (1931) may have selected the wrong hosts for study because at the time, only 3 of $470 \mathrm{~L}$. depurator and a few of 3000 C. maenas were infected. Since then, $H$. perezi, or a closely related species, has been reported in epidemics from Cancer pagurus (Latrouite et al. 1988, Stentiford et al. 2002) and Necora puber (Wilhelm \& Boulo 1988, Wilhelm \& Mialhe 1996) off Brittany, France, and from the English Channel (Sten- 
tiford et al. 2003). A second species, H. australis, was described from Australia (Hudson \& Shields 1994). It was separated from $H$. perezi on the basis of size of the vegetative stage (trophont), the presence of rounded plasmodial stages and the austral location. Molecular studies later supported the separation of $H$. australis from other known forms of Hematodinium (Hudson \& Adlard 1996), but to date there have been no molecular or ultrastructural studies on the type species from the type host. The Hematodinium parasite from Nephrops norvegicus (Field et al. 1992) and that from Chionoecetes bairdi (Meyers et al. 1987) are no doubt new species, but until there is comparative work with the type species, it will remain difficult to place them within the genus. This lack of comparative study with the type species has hampered the taxonomy of the group. At present, there are only a few characteristics that can be used to distinguish among species. The presence in a crustacean host, the hemolymph-dwelling filamentous plasmodial stages, and the high intensity infections with amoeboid trophonts and their ever-present dinokaryon lead to the diagnosis of Hematodinium. The presence of the motile vermiform plasmodium, or filamentous trophont of Appleton \& Vickerman (1998), may be of significance in the taxonomy of the genus as it only occurs in C. maenas (Chatton \& Poisson 1931), Callinectes sapidus (Newman \& Johnson 1975, Messick 1994, Shields \& Squyars 2000) and N. norvegicus (Field et al. 1992). It has not been reported for infections in $C$. bairdi (Meyers et al. 1987, Eaton et al. 1991), but a filamentous form has been observed in tissue preparations of C. opilio from Newfoundland (J. D. Shields unpubl. data).

DNA-based molecular diagnostics techniques are applicable to Hematodinium. Nucleotide sequences of a region of the small subunit rDNA (SSU rDNA) have been identified from several isolates of Hematodinium from a number of decapod species (Hudson \& Adlard 1994, 1996, Bower et al. 2003); and that from Hematodinium sp. isolated from Callinectes sapidus is available at GenBank (accession no. AF421184 and AF286023) (Gruebl et al. 2002). While their study did not include the type genus and species (H. perezi ex Carcinus maenas), Hudson \& Adlard (1996) found substantial sequence variation among the different species of Hematodinium from Nephrops norvegicus, Chionoectes bairdi and C. sapidus. However, although recent studies have shown that parasites detected in other crab species (such as C. tanneri) are indeed species of Hematodinium, for further definition to species level using molecular-based techniques, other regions of the genome (such as the ITS region of the rDNA) must be analysed (Bower et al. 2003). That is, the existing DNA probes used for the detection of Hematodinium appear to be genus specific and not species specific (J. D. Shields pers. obs.). However, PCR primer sets are useful for diagnosing Hematodinium and have been used for verification of infections (Gruebl et al. 2002, Stentiford et al. 2002, Sheppard et al. 2003).

\section{Parasite life history}

The life cycle of the type species, Hematodinium perezi, is unknown. However, the Hematodinium parasite isolated from Nephrops norvegicus has been grown in culture (Appleton \& Vickerman 1998). Macroand microdinospores give rise to the filamentous trophont that develops into an assemblage of filamentous forms known as a 'Gorgonlocks'. The vermiform filamentous trophont has been described from the hepatopancreas of $N$. norvegicus (Field \& Appleton 1995, 1996) and appears to be identical to the motile vermiform plasmodium of Chatton \& Poisson (1931) and Shields \& Squyars (2000). The Gorgonlocks develops into either a 'clump' colony that develops into more filamentous trophonts, or it develops into a bizarre web-like plasmodial mass known as an arachnoid trophont. This becomes an enlarged arachnoid sporont that undergoes sporogony to produce sporoblasts that then develop into the macro or micro form of the

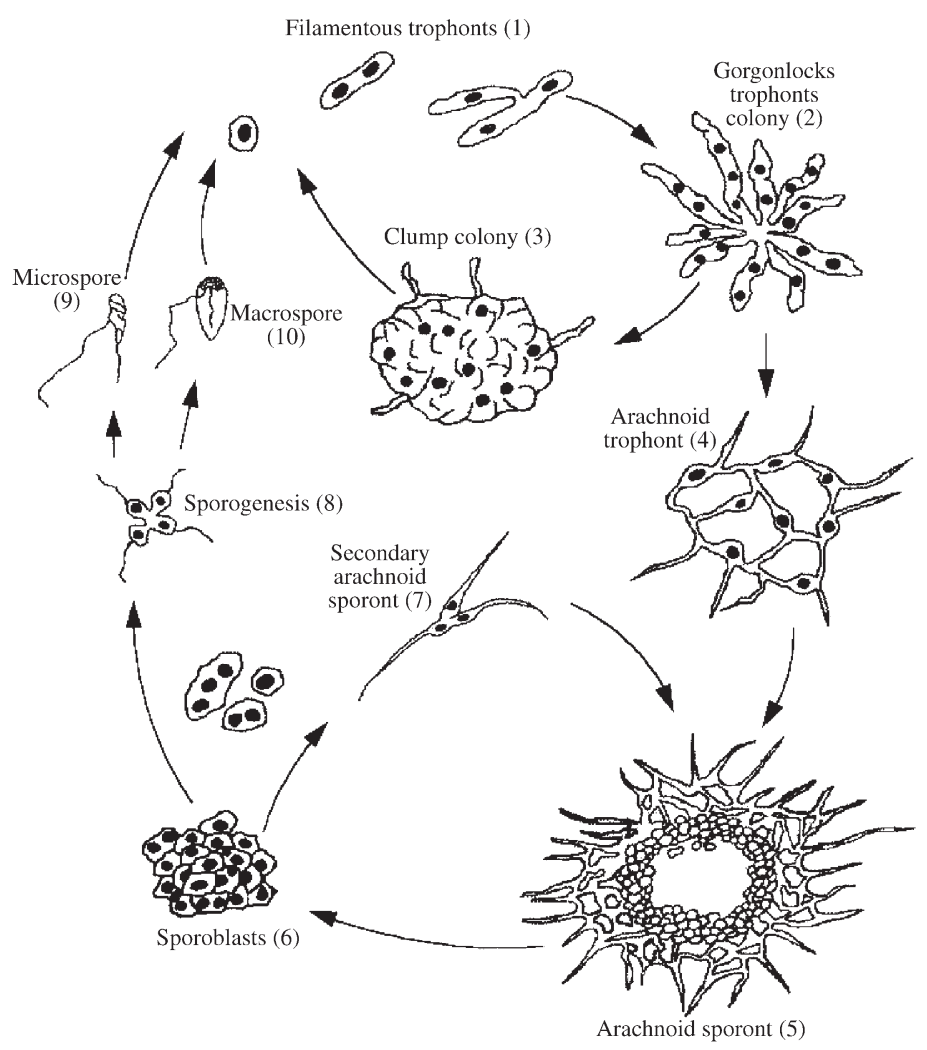

Fig. 1. In vitro life cycle for Hematodinium from Nephrops norvegicus. Taken from Appleton \& Vickerman (1998). Image courtesy of Cambridge University Press, UK 
dinospore (Fig. 1). Appleton \& Vickerman (1998) speculate that the high intensity infections observed by most researchers probably represent sporoblasts (which lead to sporogony) rather than trophic stages, but, this is unlikely given that several authors have reported similar forms in lightly infected Callinectes sapidus and Chionoecetes opilio (Meyers et al. 1987, Eaton et al. 1991, Love et al. 1993, Messick \& Shields 2000, Shields \& Squyars 2000).

Partial life cycles are known from Hematodinium parasites from 2 other host species. Eaton et al. (1991) documented the progression of life history stages present within the hemolymph of Hematodinium sp. from Chionoecetes bairdi. The ovoid plasmodial trophont produced vegetative cells (ameboid trophonts) that later developed into prespores and dinospores (Meyers et al. 1987, 1990). Macrodinospores were 12 to $14 \mu \mathrm{m}$ in size and microdinospores were 7 to $9 \mu \mathrm{m}$ in size (Meyers et al. 1987, 1990, Eaton et al. 1991). Macrodinospores may have developed into filamentous trophonts in culture (p. 213 in Meyers et al. 1987), but they were not recognized as such at the time.

The life cycle of the Hematodinium sp. isolated from Callinectes sapidus has not been fully described, but certain life history stages may be shared by it and $H$. perezi. Within the crab, its life cycle appears different to that of the parasite isolated from Nephrops norvegicus (Fig. 1). In C. sapidus, the vermiform plasmodium (cf. filamentous trophont) undergoes budding to reproduce more plasmodia, or it undergoes an apparent merogony analogous to the schizogonous segmentation of malarial parasites (Shields \& Squyars 2000), perhaps hinting at affinities within the superphylum Alveolata. The vegetative amoeboid trophonts separate during segmentation, and in turn undergo fission to produce additional trophonts. At some point in their development (perhaps as a result of high cell densities), the amoeboid trophonts undergo a final fission to produce a rounded trophont (cf. sporoblast?) that then undergoes an apparent sporogonal division to produce 4 dinospores. However, in recent culture studies, several stages of the parasite from the blue crab appear similar to those described from N. norvegicus (Fig. 2, J. D. Shields \& H. J. Small unpubl. data). Clearly, future studies need to resolve differences in the life history stages of in vitro cultures with those observed in histological sections.

While it is premature to discuss differences in the life cycle between 'species' of Hematodinium, there are nonetheless some key points that need further examination. The development of the filamentous trophonts

\section{WATER COLUMN/BENTHOS}

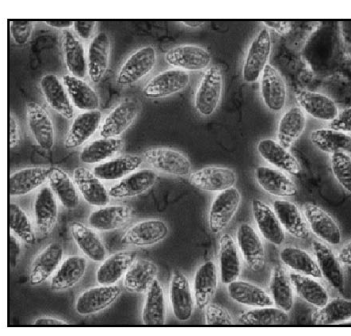

Fig. 2. Proposed life cycle for Hematodinium from Callinectes sapidus

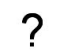

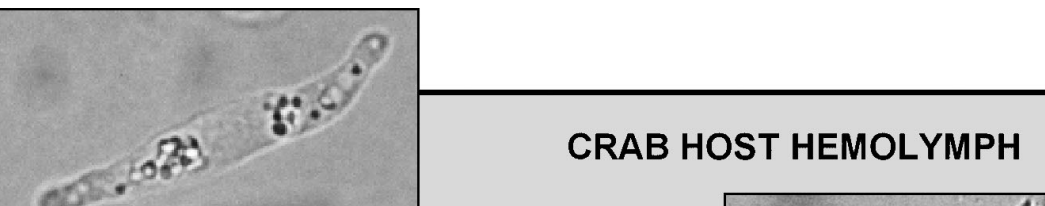
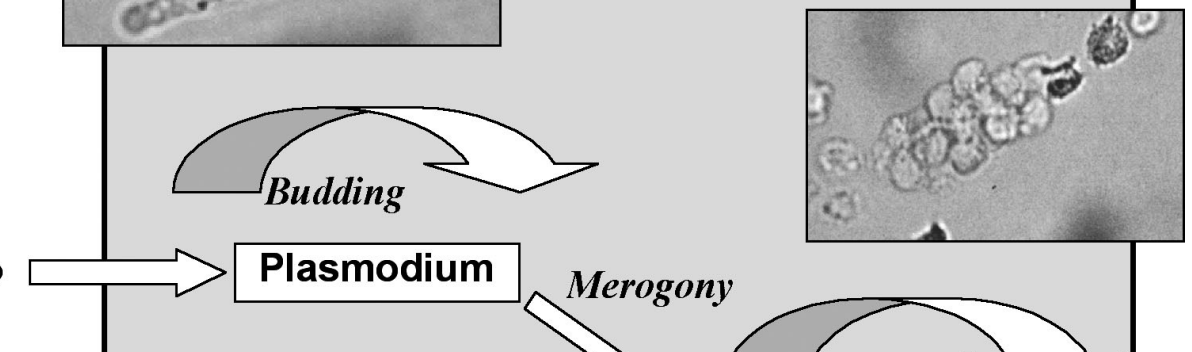

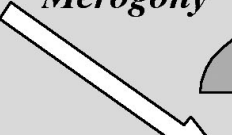
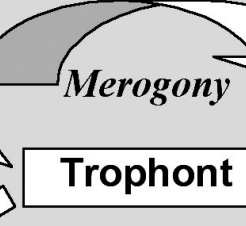

Trophont
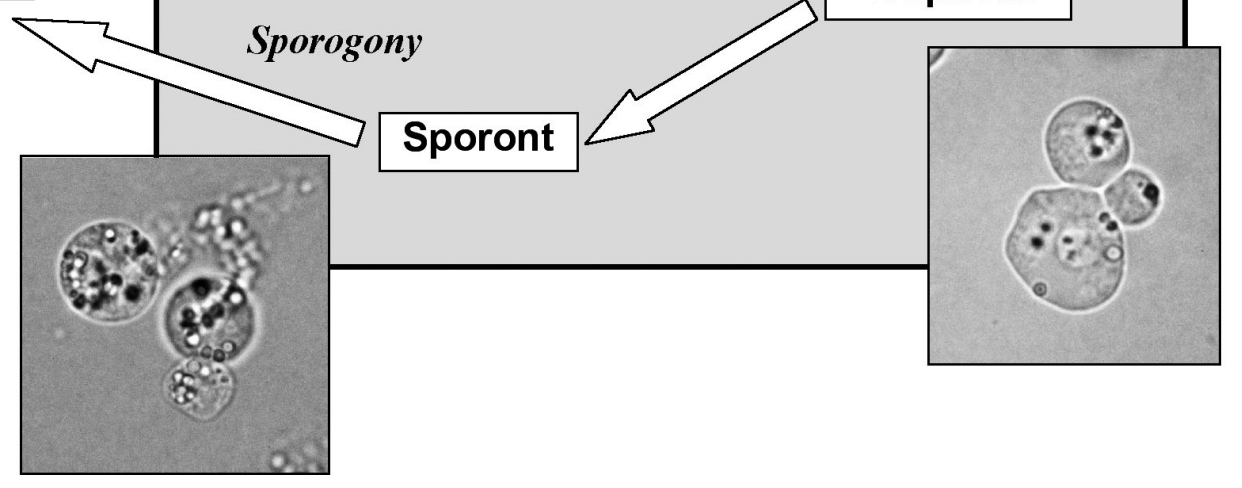
(cf. vermiform-like plasmodial stage) into the 'Gorgonlocks' morphology and the apparent arachnoidlike morphology described from the hepatopancreas of the Nephrops norvegicus (Field \& Appleton 1995, Appleton \& Vickerman 1998) have not been observed within Callinectes sapidus (Shields \& Squyars 2000, J. Shields unpubl.). In C. sapidus, the vermiform plasmodium (cf. filamentous trophont) rarely forms a Y-shaped morphology and never forms large aggregates except in cultures (Fig. 3; J. D. Shields \& H. J. Small, unpubl. data). However, the parasite in Chionoecetes opilio from Newfoundland has an apparent sheet-like plasmodial form in the hepatopancreas (Fig. 4) that resemble the arachnoid sporont and sporoblast stages described in the life cycle of the parasite isolated from $N$. norvegicus. Thus, the morphology of the multinucleate forms that occur early in the development of the infections could be taxonomically useful. Furthermore, histological analysis of the hepatopan- creas may prove fruitful to the taxonomy of Hematodinium because the early life history stages of the different parasites apparently have a predilection for this organ and develop or entwine around it (cf. Field \& Appleton 1996). Sustained in vitro cultures of Hematodinium isolated from $N$. norvegicus are not infectious (Appleton \& Vickerman 1998), nor have infections been passed serially from infected hosts to naïve hosts. This may result from a loss of infectivity or viability in cultured parasites, the lack of an appropriate infectious stage in inoculation trials, or to some host factor that infers a resistance to infection in some animals. Vegetative stages (ameboid trophonts) from primary cultures grown in sterile hemolymph were successful in establishing infections in $C$. bairdi, but inoculations with sporulating prespores did not produce infections (Meyers et al. 1987). Vegetative stages of Hematodinium from $C$. sapidus retained their infectivity after 1 wk of culture in a modified Appleton \& Vickerman
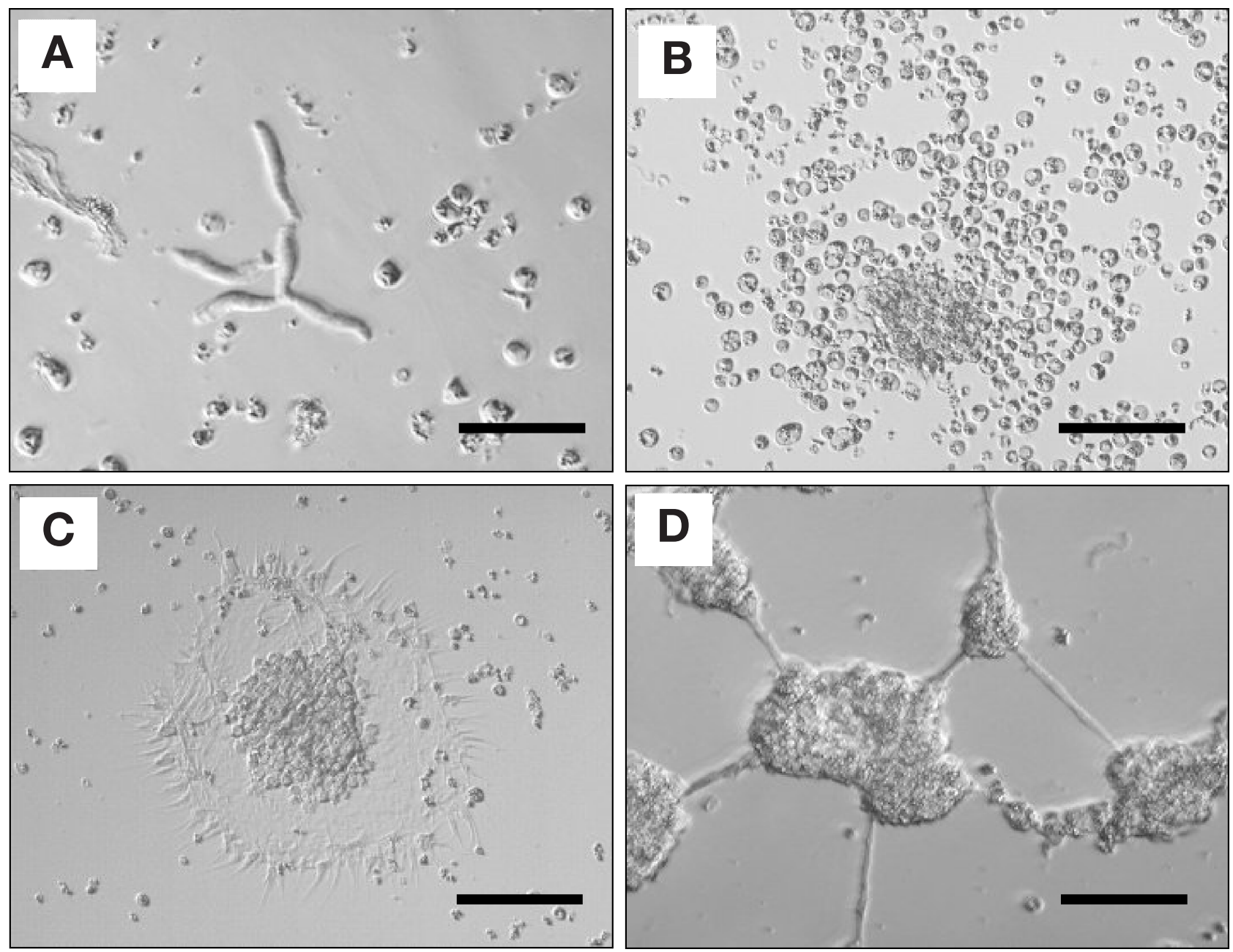

Fig. 3. In vitro life stages of Hematodinium from Callinectes sapidus. (A) Vermiform plasmodia; scale bar $=50 \mu \mathrm{m}$. (B) Trophont; scale bar $=50 \mu \mathrm{m}$. (C) Arachnoid trophont/clump colony, low power; scale bar = $100 \mu \mathrm{m}$. (D) Arachnoid trophont/clump colony; scale bar $=150 \mu \mathrm{m}$ 

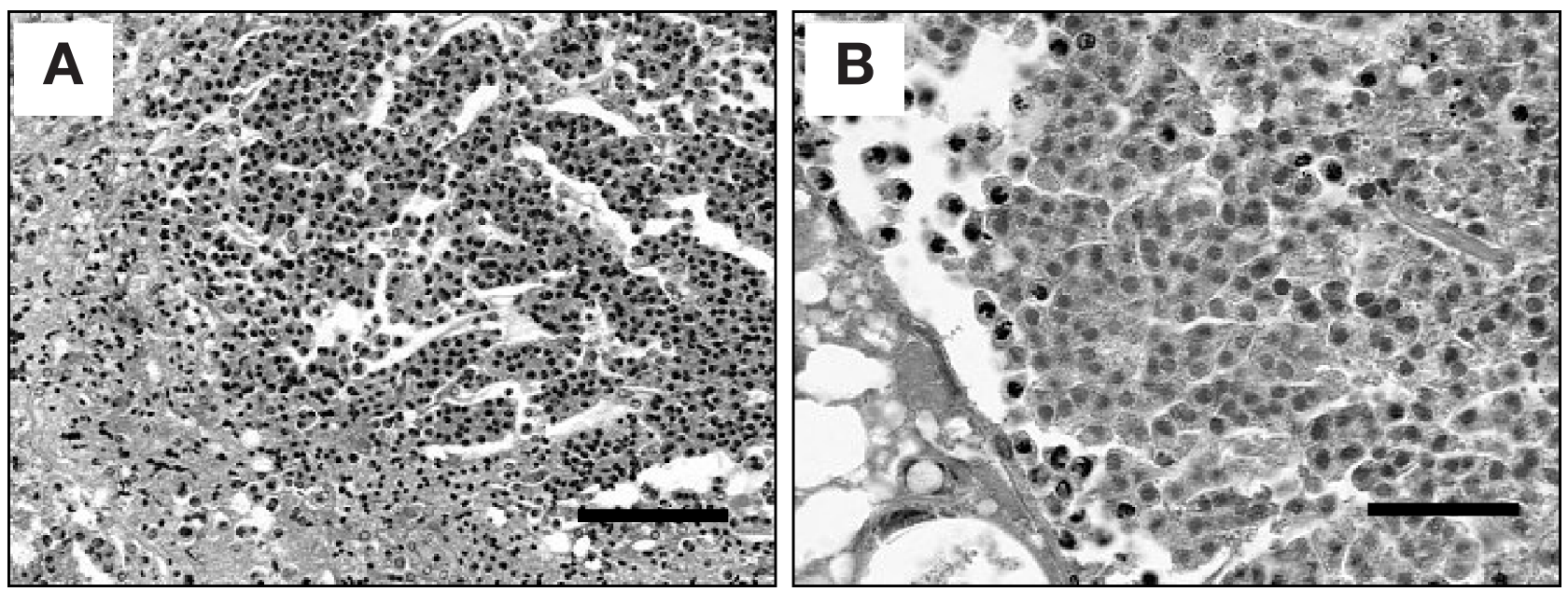

Fig. 4. Sheet-like plasmodia of Hematodinium. (A) Sinuses of heart; scale bar $=150 \mu \mathrm{m}$. (B) Hepatopancreas of Chionoecetes opilo from Newfoundland; scale bar $=75 \mu \mathrm{m}$. H\&E staining

(1998) medium (J. D. Shields unpubl.). This medium, less fetal bovine serum, has been routinely used as a buffer for challenge studies with the parasite (Shields \& Squyars 2000). The exact mode of transmission of Hematodinium to new susceptible hosts has not been fully investigated. Infections have been transmitted to uninfected hosts via inoculations of infected haemolymph for C. bairdi (Meyers et al. 1987), C. sapidus (Shields \& Squyars 2000), and Portunus pelagicus (Hudson \& Shields 1994). Inoculations experiments have also shown that filamentous trophonts and vegetative, amoeboid trophonts are capable of establishing infections (Meyers et al. 1987, Hudson \& Shields 1994, Shields \& Squyars 2000). Further, both micro- and macrospores can produce infections when inoculated into C. bairdi (Eaton et al. 1991).

Whereas the dinospore may be the infective stage, in most parasitic dinoflagellates of marine crustaceans, it is not known whether the dinospore is a true transmissive stage or simply an intermediate stage preceding a resting cyst or some other non-parasitic stage (Shields 1994). The former theory is attractive because Appleton \& Vickerman (1998) have shown that culture of dinospores leads directly to the development of filamentous trophonts (cf. vermiform plasmodium) in vitro. Sporulation from the trophont stage to the dinospore stage has been observed in several cultures of Hematodinium from Nephrops norvegicus, but in such cases, it was neither synchronous, nor abundant (Appleton \& Vickerman 1998). In laboratory infections, sporulation in Callinectes sapidus can be synchronous and occurs at least once or twice during an infection, with each event lasting from 2 to 4 d (Shields \& Squyars 2000). During synchronized sporulation, dinospore density can reach extraordinarily high levels, $1.6 \times 10^{8}$ dinospores $\mathrm{ml}^{-1}$; levels far higher than those reported from harmful algal blooms (e.g. Hallegraeff 1993, Smayda 1997). Sporulation in C. sapidus can also be asynchronous and at low densities, possibly accounting for the low number of hosts reportedly sporulating (Shields \& Squyars 2000). In N. norvegicus, sporulation is more or less synchronous, with almost complete exsporulation from the infected host (Appleton \& Vickerman 1998). Dinospores have been shown to exit the infected host via the gills in $N$. norvegicus (Appleton \& Vickerman 1998), Chionoecetes bairdi (Love et al. 1993), C. sapidus (Shields \& Squyars 2000) and Cancer pagurus (Fig. 5). Although, sporulation was not necessarily fatal in $C$. sapidus, heavily infected $N$. norvegicus and $C$. bairdi died within hours of sporulation (Love et al. 1993, Stentiford et al. 2001b). The moult stage of the host is also important to transmission, but the data are circumstantial indicating that hosts obtain infections during ecdysis or shortly thereafter (see 'Host Factors'). Further studies on the passive uptake and/or the natural route of entry of these stages are required to confirm this mode of transmission.

Meyers et al. (1996) found potential evidence for sexual transmission of Hematodinium in Chionoecetes bairdi with parasites present in the seminal fluids of the vas deferens in a few males, but the importance of this potential route of infection needs further work.

As with many protozoan infections in crabs, cannibalism is a possible mode of transmission for Hematodinium. While Hudson \& Shields (1994) were unable to transmit Hematodinium to Portunus pelagicus via ingestion of infected crab flesh, Sheppard et al. (2003) have reported successful transmission of disease to naïve Callinectes sapidus via ingestion. Both C. sapidus and Chionoecetes opilio are avid cannibals; conspecifics represent up to $25 \%$ of their diet (Laughlin 1982, Alexander 1986, Wieczorek \& Hooper 1995, 


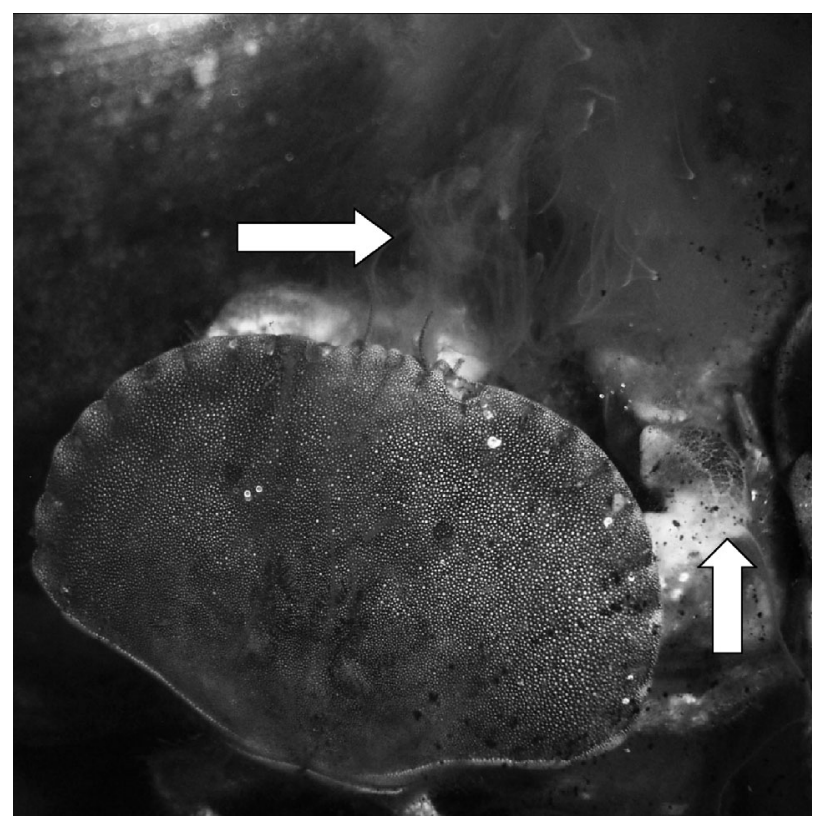

Fig. 5. Sporulation of Hematodinium in Cancer pagurus. Parasites (later identified as macrodinospores) emerge as plumes from the mouth and gill cavities of the infected host (arrows). Death ensued within a number of hours. Image courtesy of Dr. Sue Marrs, North Atlantic Fisheries College, Shetland, UK

Lovrich \& Sainte-Marie 1997, Moksnes et al. 1997, Squires \& Dawe 2003). Thus, cannibalism may be an efficient alternate mode of transmission for Hematodinium, for some host species.

\section{Diagnosis of Hematodinium infections}

A range of methods has been developed for the detection and assessment of Hematodinium infections in crustaceans. Externally, an increased opacity of the carapace of infected hosts often occurs in conjunction with a pronounced hyperpigmentation, particularly with advanced infections. Thus, the simplest diagnostic method involves an external assessment of the opaquely discoloured carapace that can be performed rapidly in the field. This method has been used as a field diagnostic tool for Hematodinium infection of Nephrops norvegicus in Scottish, Swedish and Irish waters (see Field et al. 1992, Tärnlund et al. 2000, Stentiford et al. 2001c, Briggs \& McAliskey 2002, respectively), for Cancer pagurus in the English Channel (Stentiford et al. 2002), for Chionoecetes bairdi from Alaskan waters (see Meyers et al. 1987, 1990) and for C. opilio from Newfoundland (Taylor \& Khan 1995, Dawe 2002, Pestal et al. 2003, Shields et al. 2005). However, while this method remains useful for the detection of advanced cases in heavily infected hosts, it does not detect low-level 'sub-patent' or potentially sub-patent (low-level, tissue-based) infections (see Meyers et al. 1987, Shields \& Squyars 2000, Stentiford et al. 2001c, Pestal et al. 2003), nor is it useful for infections in temperate species such as Callinectes sapidus (J. D. Shields pers. obs.). Using a double sampling and cluster sampling approach, the epidemiological characters of specificity and sensitivity were analyzed to correct for the underestimation of prevalence on the basis of visual diagnosis alone (Pestal et al. 2003). In $C$. opilio from Newfoundland, the specificity of visual diagnosis of infection was shown to be high indicating that the discolouration of the carapace by the parasite was pathognomic for the disease and that visual diagnosis was accurate for assessing this discolouration. However the sensitivity was moderate, indicating that visual diagnosis was essentially missing $48 \%$ of the infections.

Pleopod staging is a method for diagnosing Hematodinium and evaluating the severity of infection in Nephrops norvegicus (Field et al. 1992, Field \& Appleton 1995). A pleopod is removed from the abdomen and assessed for the presence of parasites using low-power microscopy. This method, which assigns a score (0-4) based on the severity of infection, has been used in field studies of Hematodinium infections in populations of $N$. norvegicus from the west coast of Scotland (Field et al. 1992, Field et al. 1998, Stentiford et al. 2001c). It allows for the detection of 4 to $50 \%$ more infected lobsters, than the carapace discolouration method. For male portunids, an assessment of the propodus of the 5th (swimming) leg has proved useful as this limb article is often flattened enough for low-power microscopic examination (Messick 1994), but pleopodal staging it is not universally applicable for diagnosis of Hematodinium infections in many species because male hosts do not possess adventitious pleopods.

For diagnosis of Hematodinium infection in crabs, the most reliable, cost-effective, permanent method is microscopic determination of prepared slides for the presence of parasites in the haemolymph. A standard haemolymph smear followed by methanol fixation and staining with a suitable histological stain such as Giemsa or haematoxylin and eosin provides consistent results (see Meyers et al. 1987, Love et al. 1993, Hudson \& Shields 1994, Messick 1994, Taylor \& Khan 1995, Wilhelm \& Mialhe 1996, Messick \& Shields 2000). Preferred, however, is a wet smear prepared on a poly-L-lysine-coated slide, that is rapidly fixed in Bouins solution or $10 \%$ neutral buffered formalin, then processed through a routine haematoxylin and eosin procedure or a modified Giemsa (Messick 1994; Messick \& Shields 2000, Shields \& Squyars 2000, Pestal et al. 2003). These techniques can easily be modified for shipboard sampling to avoid spillage of fixatives (Pestal et al. 2003). 


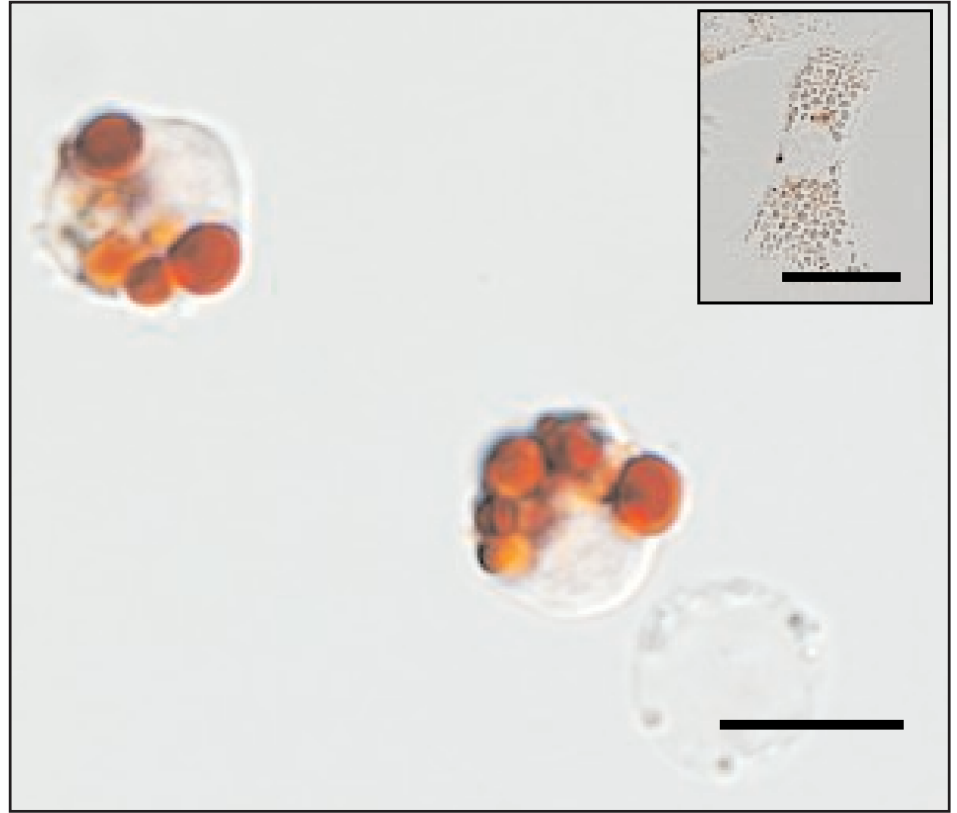

Fig. 6. Wet preparation of Hematodinium trophonts isolated from Callinectes sapidus showing retention of neutral red within large lysosomes. Inset: unstained granulocyte from same specimen. Scale bars $=20 \mu \mathrm{m}$

antibodies allowed for the objective monitoring of Hematodinium infection in the $N$. norvegicus fishery, providing more accurate data on infection-associated mortality for potential use in stock assessment models (Stentiford et al. 2001d). Further, an ELISA-based diagnostic has since been developed and it can provide an even more rapid diagnosis of the disease in this species (Small et al. 2002).

The development of PCR- and ELISAbased diagnostics for the detection of Hematodinium will lead to new advances in our understanding of the pathologies, life histories, and induced host mortalities. A $680 \mathrm{bp}$ product was originally amplified from the 3 ' end of the SSU region of the $18 \mathrm{~s}$ ribosomal DNA (Hudson \& Adlard 1994). A sequence of this product was shown to be specific to Hematodinium (Hudson \& Adlard 1996). Comparison of sequences from several infected hosts indicated that Hematodinium in Callinectes sapidus was different from those in Nephrops norvegicus, Chionoecetes bairdi and $C$. opilio, and that parasites in the latter 2 hosts from off Alaska were quite similar. Additional

Fresh hemolymph smears with Hematodinium parasites can be difficult to diagnose. The vermiform plasmodium (cf. filamentous trophont) is the most easily identified form, but the vegetative, amoeboid stage is that most frequently observed and to the uninitiated, it is easily confused with a hemocyte. Indeed, Hematodinium infections in blue crabs have been described as a 'neoplastic granulocytemia' (Newman 1970). However, Neutral Red is an excellent vital stain for the parasite in fresh hemolymph at least for $H$. perezi in green crabs (Chatton \& Poisson 1931) and infections in blue crabs (J. D. Shields unpubl. data). The dye is taken up by into the lysosomes of the parasite and host hemocytes acquire little of the stain. Neutral Red has the advantage of providing a visual contrast and can thus be used for diagnostic purposes (Fig. 6). However, Neutral Red does not stain Hematodinium from Nephrops norvegicus (H. J. Small unpubl. data), and, thus is not a good indicator for Hematodinium infections in general. Janus Green has also been used as a vital stain (Chatton \& Poisson 1931) but its use as an indicator of infections has not been evaluated.

An indirect immunofluorescent antibody technique (IFAT) was developed using antibodies raised against cultured Hematodinium parasites originally isolated from Nephrops norvegicus (Field \& Appleton 1996, Appleton \& Vickerman 1998). The IFAT revealed that some apparently uninfected $N$. norvegicus harboured sub-patent infections (Field \& Appleton 1996). The development of a Western-blot technique using these primer sets have been developed for the Hematodinium parasites in C. sapidus (Gruebl et al. 2002, Sheppard et al. 2003). Using these new primers, several sub-patent infections were detected in blue crabs. Further, the sensitivity of the primer set was estimated at 1 parasite cell per 300,000 host hemocytes. While PCR-based diagnostics are unlikely to be useful for large-scale field monitoring of infections, ELISAbased methods, such as that developed by Small et al. (2002), are highly sensitive and could be applied in field situations. Lastly, the expression and sequencing of elements of the parasite's genome using the PCR technique is likely to prove fruitful in establishing the taxonomic link between Hematodinium perezi and the Hematodinium-like parasites infecting other crustacean hosts, for studies on the life cycle and possibility of vectors in the life cycle, for detection of over-wintering and for cryptic infections and can also be used for detecting low level infections established during laboratory transmission studies (e.g. using in situ hybridisation techniques on histological preparations).

\section{PATHOLOGY OF INFECTION}

\section{External observations}

A common feature of Hematodinium infections is a hyperpigmentation of the carapace of the host which is often accompanied by a 'chalky' or 'cooked' appear- 
ance and a discolouration of arthrodial membranes and genital pores in females (e.g. see Fig. 1 in Pestal et al. 2003). Though the mechanisms for this colour change have not been investigated, a number of studies have given clues as to its causality, such as glycogen depletion or hormonal disruption. Glycogen is depleted in patent infections of Hematodinium (Stentiford et al. 2000b, Shields et al. 2003). As glycogen is required for the synthesis of chitin (Stevenson 1985), it is possible that a reduction in glycogen could lead to alterations in chitin deposition to the exoskeleton, and in turn to its altered colouration and translucency. Because Hematodinium infections appear more prevalent in recently moulted hosts (Meyers et al. 1987, Eaton et al. 1991, Wilhelm \& Mialhe 1996, Field et al. 1998, Stentiford et al. 2001c, Shields et al. 2005), it is plausible that the depletion of glycogen reserves interfere with the normal deposition of new chitin. Alternatively, recent evidence has suggested that hormonal disruption can occur during Hematodinium infection in Nephrops norvegicus (Stentiford et al. 2001a). Although, not specifically tested, an alteration in the synthesis and release of various pigment dispersing and concentrating hormones, similar to that described for the crustacean hyperglycaemic hormone $(\mathrm{CHH})$ (Stentiford et al. 2001a) could be responsible for the colour changes observed in infected hosts.

\section{Hemolymph}

Circulating hemocytes of normal, healthy crustaceans play a role in wound repair, clotting, phagocytosis, nodulation and encapsulation of foreign material, tanning of the cuticle, carbohydrate transport, glucose regulation, haemocyanin synthesis, and possibly osmotic regulation (e.g. Bauchau 1981). Crabs and lobsters infected with Hematodinium exhibit hemocytopenia, or a decline in hemocytes, with infection (Shields 1994, Field \& Appleton 1995, Shields \& Squyars 2000). However, quantitative data on changes in hemocyte densities have only been reported for one host species. Experimentally infected Callinectes sapidus showed a significant and rapid decline in absolute densities of circulating hemocytes (48\% decline) within $3 \mathrm{~d}$, and an even more dramatic decline (70 to $80 \%$ ) within $21 \mathrm{~d}$ of inoculation (Shields \& Squyars 2000). Relative declines were noted primarily in hyalinocytes, hemocytes that function in coagulation and clot formation. Similar changes were noted in the hemograms of naturally infected crabs. Interestingly, hemograms from several crabs that were refractory to infection showed relative increases in granulocytes with relative declines in semigranulocytes and no changes in densities of hyalinocytes. The hemograms of these crabs were essentially identical to that of the uninfected crabs $40 \mathrm{~d}$ after exposure (Shields \& Squyars 2000).

Hematodinium can exhibit rapid logarithmic growth within a host (Shields \& Squyars 2000). The resulting massive number of parasites during patent Hematodinium infections likely imparts the opaque to creamy colouration to the hemolymph of infected hosts (Newman \& Johnson 1975, MacLean \& Ruddell 1978, Meyers et al. 1987, Field et al. 1992, Love et al. 1993, Hudson \& Shields 1994, Messick 1994, Shields 1994, Field \& Appleton 1995, Taylor \& Khan 1995, Wilhelm \& Mialhe 1996, Taylor et al. 1996, Shields \& Squyars 2000, Stentiford et al. 2002). The hemolymph of heavily infected crabs also shows a distinct coagulopathy, or lack of clotting ability (Meyers et al. 1987, Hudson \& Shields 1994, Shields \& Squyars 2000). Loss of clotting of the hemolymph is common to many microbial and parasitic infections of decapods. The clotting mechanisms may be specifically suppressed or reduced as indicated by hemocytopenia, more specifically the decline in hyalinocytes, which regulate coagulation (Bauchau \& DeBrouwer 1972, Ghidalia et al. 1981, Durliat 1989, Hose et al. 1990, Martin et al. 1991, Shields \& Squyars 2000). Pauley et al. (1975) suggested that the lack of clotting in Paramoeba infections in the blue crab was due to alterations of the hemolymph resulting from parasite-modulated proteolytic activity or from the loss of serum fibrinogen as a component of the total serum protein. Such alterations occur in the hemolymph of Callinectes sapidus infected with Hematodinium (Shields et al. 2003), but their role in coagulopathies remains to be determined.

\section{Muscle}

Muscle is the main commercial product extracted from crustaceans. During Hematodinium infections, the gross appearance of the musculature of the host is altered in terms of its water content, mechanical structure and texture (Meyers et al. 1987, Field et al. 1992, Messick 1994, Hudson 1995, Wilhelm \& Mialhe 1996). Considerable alterations occur in the biochemistry of the abdominal musculature of Nephrops norvegicus during Hematodinium infection, with only a slight increase in water content (Stentiford et al. 2000b). In a study on the pathology of Hematodinium infection of $N$. norvegicus, Field \& Appleton (1995) recorded the presence of uninucleate plasmodia and syncitial networks in the abdominal muscle fibre interstices, with a concomitant decrease in connective tissue. A similar finding was reported for infected Portunus pelagicus (Hudson \& Shields 1994). Field \& Appleton (1995) also reported lysis of peripheral fibre 
regions and a separation of the sarcolemma from the myofibrils. These findings were later confirmed by electron microscopy (Stentiford et al. 2000b). For Hematodinium infections in Cancer pagurus, the histopathological alteration in the muscle was more severe, with almost complete degeneration of the claw musculature (Stentiford et al. 2002). In this case, the remaining intact muscle fibres also showed a separation of the sarcolemma from the contractile myofibrils at the fibre periphery. This was in contrast to the mild pathology of the abdominal muscle recorded in $N$. norvegicus, which showed severe disorganisation of filaments in the region of the Z-line (Stentiford et al. 2000b). Muscular degeneration also occurs in Chionoecetes opilio that are heavily infected with Hematodinium but the nature of this pathology remains to be determined (Fig. 7, J. D. Shields unpubl. data).

\section{Hepatopancreas}

The hepatopancreas of decapod crustaceans produces digestive enzymes and facilitates the absorption and storage of nutrients. Physiological abnormalities caused by disease are likely to be manifested in this organ (e.g. Johnson 1980). The hepatopancreas is often extracted from crustaceans, particularly crabs, as an important food product known as 'tamale' or 'brown meat'. In Nephrops norvegicus, the filamentous trophonts and early arachnoid sporont have an apparent predilection for the hepatopancreas (Field \& Appleton 1996, Appleton \& Vickerman 1998, Stentiford et al. 2001d). Parasites have been observed in close association with, and possibly even attached to, the basal lamina of the hepatopancreas (Stentiford et al. 2003) (Fig. 8). In patently infected hosts, the hepatopancreas exhibits a
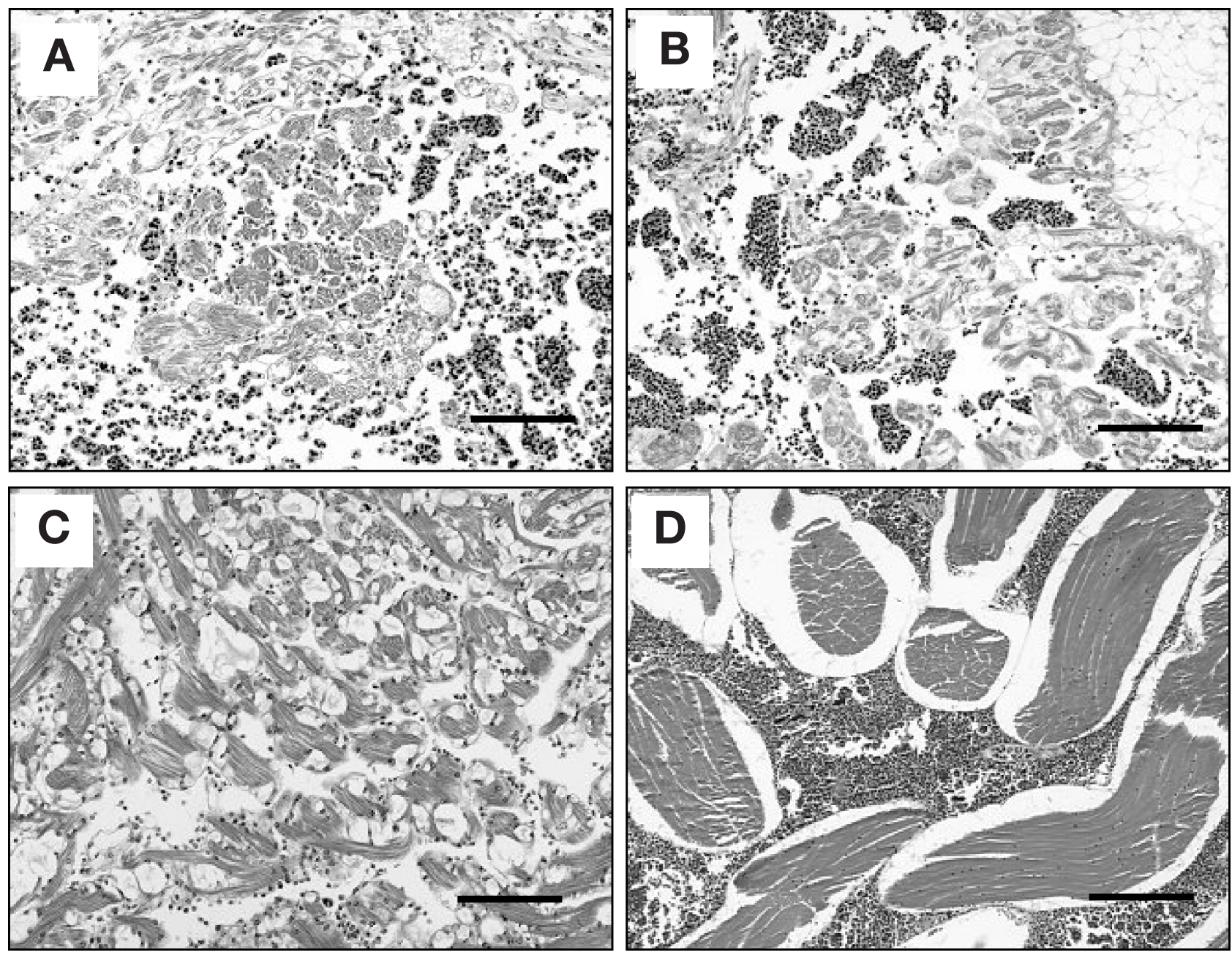

Fig. 7. Muscular pathology in Chionoecetes opilio infected with Hematodinium. (A) Heart showing dilation of hemal sinuses with massive infiltration by parasitic cells; scale bar $=200 \mu \mathrm{m}$. (B) Heart with no infiltration of pericardium but dilation of hemal sinus with large masses of parasites; scale bar $=200 \mu \mathrm{m}$. (C) Heart, uninfected crab for comparison; scale bar $=200 \mu \mathrm{m}$. (D) Claw musculature showing dilation of hemal spaces and degeneration of musculature; scale bar $=300 \mu \mathrm{m}$. H\&E staining 
loss of structural integrity and is often coated with creamy, friable deposits (see Meyers et al. 1987, Field et al. 1992, Field \& Appleton 1995, Stentiford et al. 2002). During patent infections, the haemal arterioles of the hepatopancreas are grossly dilated and filled with large numbers of parasitic plasmodial cells (MacLean \& Ruddell 1978, Meyers et al. 1987, Hudson \& Shields 1994, Field \& Appleton 1995, Wilhelm \& Mialhe 1996, Stentiford et al. 2002). In heavy infections, the hepatopancreatic tubules degenerate and parasites are often found within the lumen of the intact tubules (Meyers et al. 1987, Field \& Appleton 1995, Stentiford et al. 2002). Disruption to this organ likely results in a breakdown in the normal digestive process, possibly explaining why lipid storage products are much reduced within the R-cells of the hepatopancreatic tubules (Stentiford et al. 2002). With TEM, remnants of degenerated host tissue (such as atrophied mitochondria, myelin bodies and membranous material) were found surrounding plasmodia on the periphery of the remaining tissues (Stentiford et al. 2002). In heavy infections, the haemal arterioles were infiltrated by massive numbers of parasites that presumably resulted in pressure necrosis to the fixed phagocytes and blood vessels in the hepatopancreas. Pressure-induced necrosis may also impact upon the hepatopancreatic tubules by reducing their ability to function normally. The digestive and detoxification abilities of the hepatopancreas of infected hosts have not been examined.

\section{Other organs and tissues}

Due to the coelomic habit of Hematodinium, it is not surprising that plasmodial forms have also been described infiltrating other organs and tissues. Field \&

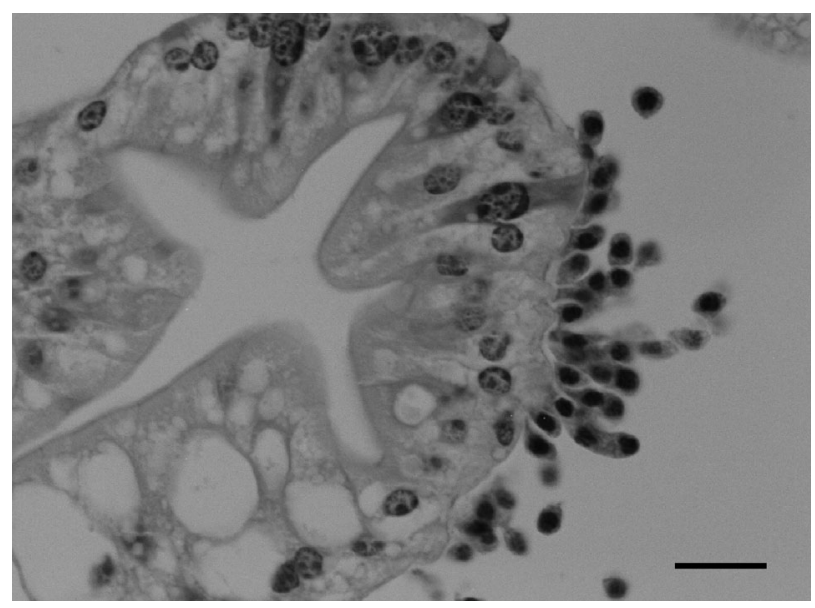

Fig. 8. Hepatopancreas of Hematodinium infected Nephrops norvegicus showing attachment of plasmodia to the basal lamina of tubule epithelial cells. Scale bar $=25 \mu \mathrm{m}$. H\&E staining
Appleton (1995) and Meyers et al. (1987) have recorded occlusion of the haemal spaces of the gill, heart, eyestalk and brain by parasites. In addition, Field \& Appleton (1995) also reported large-scale infiltration of the connective tissue of the gut, while Meyers et al. (1987) noted congestion of the sinuses of the antennal gland by parasites. The disruption to normal hematopoiesis as reported by Field and Appleton (1995) may partly explain the vast reduction in haemocyte densities reported in Hematodinium-infected hosts (see Meyers et al. 1987, Shields 1994, Field \& Appleton 1995), but in experimentally infected Callinectes sapidus, the reduction in haemocytes was significant within $3 \mathrm{~d}$ of infection and was more likely due to cellular interactions rather than a disruption in haematopoiesis (Shields \& Squyars 2000). Pressure necrosis, degranulation of granulocytes or atrophy of hyalinocytes will also lead to a decline in haemocytes, but there is limited evidence that host haemocytes attack or respond to these parasites.

Parasitic dinoflagellates of copepods and amphipods are typically parasitic castrators (Shields 1994), but castration has not been examined in crabs or lobsters infected by Hematodinium. However, Messick \& Shields (2000) reported Hematodinium infections in ovigerous Callinectes sapidus, and Stentiford et al. (2002) observed that the arterioles in the ovary of Cancer pagurus were heavily infiltrated by parasitic plasmodia during patent infections. In this way, castration could be effected through the disruption of the testis or ovary of infected hosts. Infected female Nephrops norvegicus from the Irish Sea do not develop mature gonads (Briggs \& McAliskey 2002). However, size at maturity was not presented and would likely confound their analysis because females reach maturity between 21 and $34 \mathrm{~mm}$ (Hillis \& Tully 1993, Tuck et al. 2000). Further, the short duration and lethal outcome of infections in C. sapidus may limit the potential for castration in the population. Similarly, primiparous female snow crabs with the disease die before their egg clutches hatch. While this is not strictly speaking castration, it is a negative impact on the reproduction potential of the host and may therefore impact at the population level.

\section{Co-infections}

The immune status of Hematodinium-infected crustaceans has not been well studied. The pronounced hemocytopenia associated with severe Hematodinium infections likely hinders the normal immune response of clotting, phagocytosis, encapsulation of foreign material, initiation of the prophenoloxidase system and the production of other antibiotic factors (for review see Smith \& Söderhäll 1986, Smith \& Chisholm 1992, 
Thörnqvist \& Söderhäll 1997). Secondary infections of opportunistic pathogens occur frequently in infected hosts. Septicemia, or haemolymph infections with bacteria, a condition commonly associated with stress in crustaceans (Johnson 1983), is found to co-occur in infected Chionoecetes bairdi (Meyers et al. 1987, Love et al. 1993). In addition, bacteria are often found within the fixed phagocytes of the hepatopancreas of such hosts (Fig. 9). An unidentified ciliate has also been reported from infected C. bairdi (Meyers et al. 1987, Love et al. 1993), these generally considered facultative parasites (Anophyrs and Mesanophyrs spp.) that require a portal of entry or an otherwise compromised host (Bang 1983, Morado \& Small 1994). Their involvement with hosts infected with Hematodinium suggests a dinoflagellate-induced host immunosuppression. Recently, a yeast infection has been reported in infected Cancer pagurus and Necora puber from the English Channel (Stentiford et al. 2003). Budding forms of the yeast were found in the plasma, and the degree of host encapsulation, an indicator of immune function, varied markedly between individual crabs. Such yeast infections likely represent an opportunist taking advantage of a weakened host immune status associated with severe Hematodinium infection, but it is interesting to note that in most cases, no reactions occur toward Hematodinium parasites. Whether such opportunistic infections are implicated in the pathophysiological manifestations associated with Hematodinium infections and whether they play an important role in host mortality remains to be determined. Regardless, infections of Hematodinium may provide a useful model for studying parasite-induced immunosuppression in crustaceans.

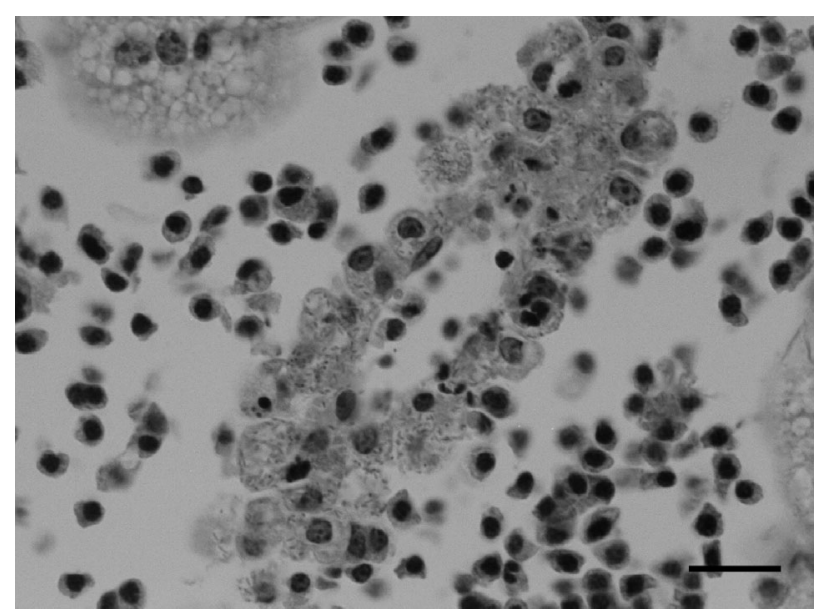

Fig. 9. Hemal sinus of Hematodinium infected Nephrops norvegicus. Unidentified bacteria are present within the cytoplasm of the fixed phagocytes surrounding a central vessel. Hematodinium cells are present within the haemal sinus. Scale bar $=25 \mu \mathrm{m}$. H\&E staining

\section{PHYSIOLOGY OF INFECTION}

Severe Hematodinium infections place a heavy, and potentially fatal, metabolic load on the host. While oxygen consumption of patently infected Nephrops norvegicus was higher than that of uninfected lobsters, the oxygen carrying capacity of the hemolymph from infected animals was reduced by over $50 \%$ (Taylor et al. 1996). A reduction in hemocyanin concentration was noted in the plasma of infected Chionoecetes bairdi (Love et al. 1996). In Callinectes sapidus, hemocyanin concentration was significantly reduced but only in heavily infected males; a reduction was not apparent in females (Shields et al. 2003). The outcomes of changes to respiratory function are tissue hypoxia and associated acidosis of the tissues and hemolymph (Taylor et al. 1996). Accordingly, lactate levels show significant change in relation to severity in infected lobsters (Taylor et al. 1996). Because hemocyanin is the primary protein in hemolymph, it is not surprising that infections also cause a major reduction in serum proteins (Love et al. 1996, Taylor et al. 1996, Shields et al. 2003). The mechanisms behind this reduction in serum proteins are not known but direct uptake of proteins from the plasma by micropores on circulating parasites (Appleton \& Vickerman 1996), disturbance in hemocyanin synthesis in the hepatopancreas (Field et al. 1992, Taylor et al. 1996), or degradation of the metabolism of the host (e.g. starvation) are likely outcomes of infection.

The logarithmic proliferation of the parasites coupled with their metabolic requirements during rapid growth rapidly drains the protein and carbohydrate constituents of the host which leads to host morbidity (Stentiford et al. 2000b, 2001a, Shields et al. 2003). Starvation, coupled with these disease processes likely results in lethargy in heavily infected hosts (Taylor et al. 1996, J. D. Shields unpubl. data). Such starvation and cessation of feeding places a further drain on the storage of glycogen. Starvation also leads to marked declines in serum protein and hemocyanin levels (Uglow 1969a,b, Stewart et al. 1972). Further, moribund animals probably suffer from hypoxia and ischemia as a metabolic effect of parasitism due to tissue destruction (e.g. Taylor et al. 1996).

\section{BIOCHEMISTRY OF INFECTION}

Crustaceans infected with Hematodinium undergo significant departures from the normal biochemical composition of the haemolymph and tissues. Changes in carbohydrate handling and tissue reserves of glycogen are significantly reduced in infected crabs and lobsters (Love et al. 1996, Stentiford et al. 2000b, 2001a, 
Shields et al. 2003). In common with other animals, glycogen is mobilised from the tissues of crustaceans as a stress response, with the liberated glucose leading to hyperglycaemia in the plasma. This system is controlled by the release of $\mathrm{CHH}$ peptides from the sinus gland, which targets the hepatopancreatic plasma membranes (Kummer \& Keller 1993), the abdominal musculature (Santos \& Keller 1993) and the hemocytes (Santos \& Stefanello 1991), causing a liberation of glucose from these major storage sites. In infected Nephrops norvegicus, plasma concentrations of $\mathrm{CHH}$ were significantly elevated in infected hosts (Stentiford et al. 2001a) and are likely due to a disruption of the normal feedback loop that controls the release of this hormone from the sinus gland. The elevated titre of plasma $\mathrm{CHH}$ during Hematodinium infection is also suggestive of an increased turnover of glucose in infected animals (Stentiford et al. 2001a). Utilization of plasma glucose by the parasite may lead to a reduction in the negative feedback response that this sugar has on $\mathrm{CHH}$ release, thereby elevating the concentration of $\mathrm{CHH}$ in the plasma. The altered release of other hormones responsible for the control of major functions has not been studied.

In Callinectes sapidus, Hematodinium infections elicit distinctly different pathophysiologies between host sexes. Serum proteins, hemocyanin, and tissue glycogen are all more heavily altered in infected males versus infected females. For example, tissue glycogen was depleted by $50 \%$ in females and $70 \%$ in males (Shields et al. 2003). In Chionoecetes opilio, tissue glycogen was depleted by $50 \%$ (J. D. Shields \& D. Taylor unpubl. data), while in Nephrops norvegicus, the glycogen in the abdominal muscles was reduced by up to $80 \%$, and was concomitant with increasing parasite burden (Stentiford et al. 2000b). While it is unclear if heavily infected crustaceans survive ecdysis, chitin deposition would likely be hindered during moulting because glycogen is a significant precursor to chitin (Stevenson, 1985). However, lightly infected $C$. sapidus have successfully moulted under laboratory conditions (J. D. Shields, unpubl. data).

Proteases, acid phosphatases, superoxide dismutases, heat-shock proteins and other 'stress' proteins are often important virulence factors in parasitic protozoa of vertebrates and invertebrates (Katakura 1986, Katakura \& Kobayashi 1988, Hervio et al. 1991, Singala et al. 1992, Vannier-Santos et al. 1995, Wiese 1998, Ismail et al. 1997, Paramchuk et al. 1997, Volety \& Chu 1997). Many of these proteins have been used to characterize virulence in relation to disease. In Hematodinium-infected Callinectes sapidus decreases in activity of $\alpha$-fucosidase, and increased activities of parasite-derived acid phosphatases, napthol AS-BI phosphohydrolase, $\beta$-galactosidase, $\beta$-glucuronidase
(Shields et al. 2003) and aspartate amino transferase (Hudson 1995) indicate major biochemical changes due to infection. Some of these may even be markers of virulence, with others signifying a general collapse of metabolic homeostasis during infection. Parasitederived acid phosphatase activity is significantly higher in the hemolymph of infected crabs (Shields et al. 2003) and in cell lysates of cultures of $H$. perezi (H. Small \& J. D. Shields unpubl. data). Proteases were also detected in extracellular products from culture supernates or lysates. Thus, differences in acid phosphatase expression and other enzymes may be useful correlates for virulence and pathogenicity in Hematodinium infections.

Changes in the plasma and tissue profiles of several nitrogenous compounds have also been reported for Hematodinium infections in crustaceans. Hudson (1995) associated elevations in the concentration of plasma urea and creatinine with a possible impairment of the urinary bladder and antennal gland apparatus. Love et al. (1996) reported an elevated concentration of ninhydrin-positive substances in the plasma of infected crabs while in similar studies using infected Nephrops norvegicus, Stentiford et al. (1999, 2000b) recorded a disturbance of the free amino acid profile of plasma and muscle. Tissue and haemocyte degradation and the induction of a generalized host stress response were associated with an increase in the concentration of taurine during infection. Such changes, in addition to those recorded for salts in the plasma (Hudson 1995, Love et al. 1996) indicate a departure from the normal electrolyte status of infected hosts. Whether this departure helps to explain why Hematodinium infections in Callinectes sapidus are not reported from low salinity areas is speculative. Interestingly, the significant elevation in plasma $\mathrm{CHH}$ seen in late-stage Hematodinium infections of $N$. norvegicus has been linked to the uptake of water (Stentiford et al. 2001a), a feature this hormone elicits in healthy animals during ecdysis (Chung et al. 1999). An increase in haemolymph volume or pressure during the final stages of a patent infection would coincide with maximal numbers of circulating motile dinospores which are known to exit the host via ruptured gills, arthrodial membranes and the gut at this time. However, changes in hemolymph pressure during sporulation are difficult to study given its errant timing.

The processes leading to host death in Hematodinium infections are not well understood. Respiratory dysfunction is evident by the decline in hemocyanin levels (Field et al. 1992, Shields et al. 2003), the loss of oxygen binding capacity of the hemocyanin (Taylor et al. 1996), and the magnitude of parasitic congestion and disruption of the gills and other tissues (Meyers et al. 1987, Field et al. 1992, Field \& Appleton 1995, 
Hudson \& Shields 1994, Messick 1994, Stentiford et al. 2002). Ischemia with focal necrosis results from Vibrio spp. infections in Callinectes sapidus (Johnson 1976). However, the chronic nature of Hematodinium infections indicates that starvation and exhaustion of metabolic reserves (e.g. decreased glycogen) occurs and likely results from proliferation of the parasite (Meyers et al. 1987, Shields \& Squyars 2000, Stentiford et al. 2000b, Shields et al. 2003) in conjunction with reduced feeding activity associated with morbidity (Taylor et al. 1996, Stentiford et al. 2000b). Changes in osmoregulation resulting from shifts in plasma proteins, amino acids and other compounds, leading to osmotic collapse, likely contribute to the cause of death (Stentiford et al. 1999). Declines in haemocyte densities are highly correlated with imminent host death (Shields \& Squyars 2000), and would facilitate the development of lethal secondary infections reported from hosts with Hematodinium infections (Meyers et al. 1987, Field et al. 1992, Stentiford et al. 2003), or lead to the loss of clotting ability with death ensuing from loss of hemolymph (Shields et al. 2003).

\section{EPIZOOTIOLOGY}

\section{Host range and reservoir hosts}

Hematodinium infections have been reported from several crustacean hosts from around the world, with the majority of infections reported in brachyuran crabs (Table 1). The broad range of brachyuran hosts suggests that these parasites are host generalists, with perhaps some species infecting different classes of Crustacea (Amphipoda and Decapoda), but tests of host specificity await refinements in molecular tools. The Hematodinium-like parasite from the spot prawns, Pandalus borealis and P. platyceros (Bower et al. 1993, Meyers et al. 1994, Bower \& Meyer 2002) is apparently more closely allied with the Haplosporidia and is not a dinoflagellate (Reece et al. 2000).

Hudson \& Shields (1994) and Shields (1994) have speculated that amphipods may act as alternate or reservoir hosts for Hematodinium. Small (2004) recently showed that PCR primers specific for Hematodinium in Nephrops norvegicus also amplify products from amphipods. While these primers indicated that the parasite in amphipods was a species of Hematodinium, they are likely genus specific, making it difficult to draw further conclusions. However, crustaceans, including amphipods, make up a significant portion of the diet (up to $25 \%$ ) of juvenile Callinectes sapidus, Chionoecetes opilio and even N. norvegicus. Since amphipods reportedly carry a similar infection (John- son 1986, Small 2004), then their role in transmission of the disease needs to be investigated. Infection trials exposing amphipods to infected tissues or carcasses of infected crabs or lobsters may provide insight into the life cycle of the parasites and potentially elucidate the role of amphipods as reservoir hosts. A similar approach recently uncovered a role for copepods in the life cycle or transmission of Marteilia refringens in oysters (Audemard et al. 2002). Further refinements in PCR-based assays should focus on differentiating between species of Hematodinium, as these will no doubt facilitate identification of alternate or reservoir hosts.

\section{Host factors}

Crustaceans appear to be particularly vulnerable to infection during ecdysis, oviposition, and sexual contact. Accordingly, the prevalence and abundance of Hematodinium infections show distinct patterns of association with several host factors including size or age (Field et al. 1992, 1998, Messick 1994, Stentiford et al. 2001c), sex (Field et al. 1992, Shields et al. 2003, Stentiford et al. 2001c) and moult condition (Meyers et al. 1987, 1990, Eaton et al. 1991, Field et al. 1992, Shields et al. 2005). The effects of these host factors in relation to disease prevalence should be considered in further studies on this infection. For example, during summer peaks in infections, newly moulted Chionoecetes bairdi and C. opilio have a higher prevalence of Hematodinium than do 'old' shell crabs that have not moulted within the last year or 2 (Meyers et al. 1990, Eaton et al. 1991, Dawe 2002, Shields et al. 2005). Whereas Meyers et al. (1990) and Eaton et al. (1991) speculate that transmission to new hosts occurs during the moulting period of the crabs, sporulation occurs after the primary spring moulting period for these crabs. Further, the higher prevalence in 'new shell' or recently moulted animals was presumably not due to their acquiring recent infections because infections were thought to take at least 15 to 18 mo to develop (Meyers et al. 1990). However, infections in $C$. opilio appear to take 9 to 12 mo to develop with moulting more clearly associated with transmission than it is in $C$. bairdi (Shields et al. 2005). In Nephrops norvegicus, sporulation of Hematodinium occurs just prior to the primary moulting period and appears associated with transmission of the disease (Field et al. 1992, 1998). Stentiford et al. (2001c) showed that the synchrony of the moulting seasons between males and females plays an important role in the pattern of infection within a particular year. In years when moulting was fairly synchronous (possibly due to a large proportion of size-matched 
Table 1. Host species infected with Hematodinium or Hematodinium-like parasites

\begin{tabular}{|c|c|c|c|}
\hline Group & Host species & Location & Initial source \\
\hline \multirow[t]{27}{*}{ Crabs } & Callinectes sapidus & Eastern USA & Newman \& Johnson (1975) \\
\hline & Callinectes similes & Eastern USA & Messick \& Shields (2000) \\
\hline & Cancer borealis & NY Bight & MacLean \& Ruddell (1978) \\
\hline & Cancer irroratus & NY Bight & MacLean \& Ruddell (1978) \\
\hline & Cancer pagurus & Bay of Biscay, France & Latrouite et al. (1988) \\
\hline & Cancer pagurus & English Channel & Stentiford et al. (2002) \\
\hline & Carcinus maenas & English Channel & Chatton \& Poisson (1931) \\
\hline & Carcinus maenas & Eastern USA & Messick \& Shields (2000) \\
\hline & Chionoecetes bairdi & SE Alaska & Meyers et al. (1987) \\
\hline & Chionoecetes opilio & Newfoundland, Canada & Taylor \& Khan (1995) \\
\hline & Chionoecetes opilio & $\begin{array}{l}\text { Gulf of Alaska, Bering Sea, } \\
\text { Chuckchi Sea }\end{array}$ & Meyers et al. (1996) \\
\hline & Chionoecetes tanneri & British Columbia & Bower et al. (2003) \\
\hline & Hexapanopeus angustifrons & Eastern USA & Messick \& Shields (2000) \\
\hline & Libinia emerginata & Eastern USA & Sheppard et al. (2003) \\
\hline & Liocarcinus depurator & Bay of Biscay & Chatton \& Poisson (1931) \\
\hline & Maja squinado & Bay of Biscay, France & D. Latrouite (unpubl.) \\
\hline & Menippe mercenaria & Eastern USA & Sheppard et al. (2003) \\
\hline & Necora puber & Bay of Biscay, France & Wilhelm \& Boulo (1988, Wilhelm \& Mialhe (1996) \\
\hline & Necora puber & English Channel & Stentiford et al. (2003) \\
\hline & Neopanope sayi & Eastern USA & Messick \& Shields 2000, Sheppard et al. (2003) \\
\hline & Ovalipes ocellatus & NY Bight & MacLean \& Ruddell (1978) \\
\hline & Panopeus herbstii & Eastern USA & Messick \& Shields (2000) \\
\hline & Portumnus latipes & France & Chatton (1952) \\
\hline & Portunus pelagicus & Moreton Bay, Australia & Shields (1992), Hudson \& Shields (1994) \\
\hline & Scylla serrata & Moreton Bay, Australia & Hudson \& Lester (1994) \\
\hline & Trapezia areolata and & & \\
\hline & T. coerulea & Great Barrier Reef, Australia & Hudson et al. (1993) \\
\hline Lobsters & Nephrops norvegicus & Eastern Atlantic & Field et al. (1992) \\
\hline Amphipods & $\begin{array}{l}\text { Ampelisca agassizi, } \\
\text { A. vadorum, A. verrilli, } \\
\text { Byblis serrata, Casco } \\
\text { bigelowi, Harpinia } \\
\text { propinqua, Letpocheirus } \\
\text { pinguis, Melita dentata, } \\
\text { Monouclodes edwardsi, } \\
\text { Protohaustorius wigley, } \\
\text { Phoxocephalus holbolli, } \\
\text { Rhepoxynius epistomus, } \\
\text { Unciola spp. }\end{array}$ & Eastern USA & Johnson (1986), Messick \& Shields (2000) \\
\hline
\end{tabular}

individuals in the population), a sharp peak of infection was seen. In years when moulting was asynchronous, an extended lower-level 'plateau' of prevalence occurred (Fig. 10). In Callinectes sapidus, the link between moulting and infection is more uncertain since the summer peaks in infection occur after the main spring and summer moulting periods (Messick 1994, Shields 1994, Messick \& Shields 2000). Further, the rapidity (30 to $40 \mathrm{~d}$ ) with which the disease progresses in Callinectes sapidus (Shields \& Squyars 2000) indicates that moulting is perhaps not a significant host factor in this system as outbreaks occur primarily over 2 to $4 \mathrm{wk}$ periods in autumn, well after the spring and summer moulting periods (Messick \& Shields 2000).

\section{Host size and sex}

Host size, or maturity status, and sex are important factors in virtually all commercially important hosts of Hematodinium. In Callinectes sapidus, infections appear significantly more abundant in juvenile than adult hosts (Messick 1994, Messick \& Shields 2000). Shields (1994) and Messick \& Shields (2000) speculated that juveniles might be more susceptible because they moult more frequently than adults and either obtain the disease at ecdysis or undergo stress more frequently at this time. Prevalence varies between female and male blue crabs depending on their migratory patterns (Messick \& Shields 2000), but infections in male C. sapidus are apparently more severe (Shields 

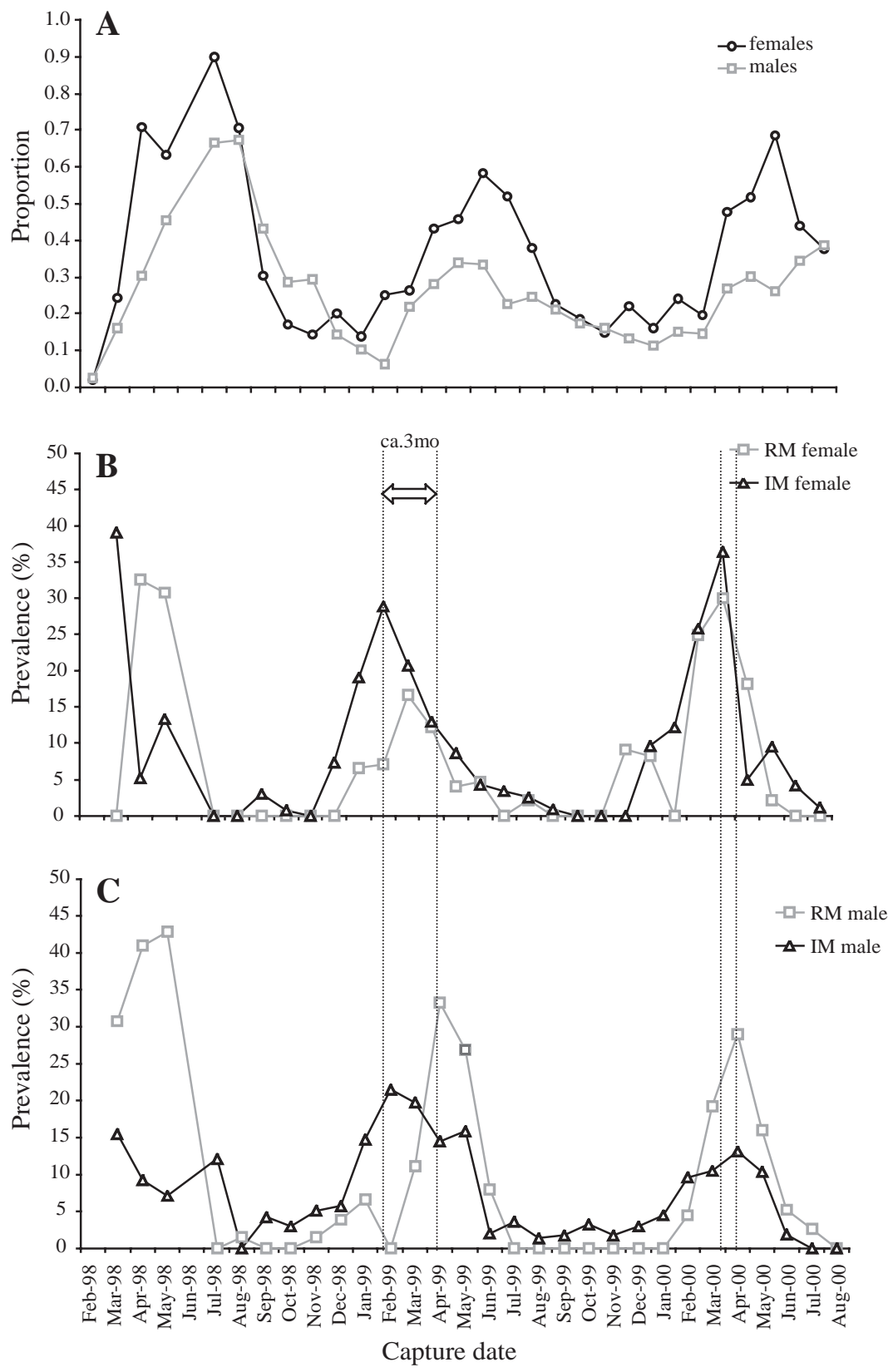

Fig. 10. Nephrops norvegicus. (A) Proportions of recently moulted (RM) and intermoult (IM) male and female lobsters. Infection prevalence in (B) RM and IM female and (C) male lobsters in the Firth of Clyde, Scotland, between March 1998 and September 2000. Broken lines in (B) and (C) compare RM and IM infection prevalence in female and male lobsters. From Stentiford et al. (2001c). Image courtesy of Academic Press, UK

et al. 2003). In Nephrops norvegicus, host size and sex appears to be a significant factor in infection and prevalence is highest in small females, with peak infection periods in the spring (Field et al. 1998, Stentiford et al. 2001c). In Necora puber, off France, no differences were observed in prevalences with host size, and host sex was not examined (Wilhelm \& Boulo
1988). In both Chionoecetes opilio and $C$. bairdi, there is considerable size dimorphism between sexes and the collection bias is for large, male crabs that have a relatively low prevalence. However, fishery independent surveys off Newfoundland indicate that females have a significantly higher prevalence than males (Dawe 2002, Pestal et al. 2003, Shields et al. in press). Juvenile $C$. sapidus apparently have higher prevalences than adults, but juveniles and females are considerably smaller than large males and are not fished, thus, their prevalences are not typically noted by the industry (Dawe 2002, Shields et al. 2005). In C. bairdi off Alaska, no differences were noted in prevalence between sexes but prevalences were extremely high and may have obscured any pattern (Meyers et al. 1987).

\section{Seasonality}

The seasonality of infection has emerged as a significant epidemiological feature of almost every Hematodinium-decapod infection model studied to date. Long-term datasets for the prevalence of infections in Nephrops norvegicus from the Clyde Sea Area, Scotland, have shown that prevalence is highest in winter and spring (Field et al. 1992, Field et al. 1998, Stentiford et al. 2001c, 2001d), reaching as high as $70 \%$ in notable epizootics (Field et al. 1992). In the Irish Sea prevalences reached 18 and 35\% (Briggs $\&$ McAliskey 2002), and showed a seasonal pattern with a nadir in the summer and fall. In the Chionoecetes bairdi fishery of southeastern Alaska, the carapace discoloration of infected crabs becomes more pronounced as the epizootics progress into the fall (Meyers et al. 1990). In hemolymph surveys, prevalences increased through spring, peaked in summer, from June through August, then declined into fall and winter as infected crabs died (Meyers et al. 1990, Eaton et al. 1991, Love et al. 1993). Meyers et al. (1990) and Love et al. (1993) found that sporogony of Hematodinium in C. bairdi was seasonal with sporulation occurring in the summer months. They speculated that transmission was occurring at this time, but noted the lack of detectable infections in the winter. The prevalence of Hematodinium in Callinectes sapidus exhibited a strong peak in prevalence during the autumn with a markedly rapid decline in winter fol- 
lowed by moderate increases in the spring (Messick \& Shields 2000, Sheppard et al. 2003). Epizootics in Callinectes sapidus have reached $100 \%$ prevalence in focal outbreaks (Messick 1994) with most of the diseased crabs likely dying of the infection (Messick \& Shields 2000, Shields \& Squyars 2000). Infections in spider crabs Libinia emarginata followed similar patterns to those in blue crabs albeit the disease was not prevalent in the spring (Sheppard et al. 2003). In Necora puber off France, over the course of 13 mo, Hematodinium infections showed a peak in the fall and nadir in the winter followed by a large-scale epizootic in the spring. This pattern varied regionally within the fishery and the epizootic likely masked the typical pattern in seasonality (Wilhelm \& Mialhe 1996). Infections in Cancer pagurus showed little seasonality off France, with prevalences ranging up to $65 \%$ in January, but several spring samples showed more consistent peaks through several years (Latrouite et al. 1988). Thus, most infections of Hematodinium exhibit strong seasonal peaks in prevalence, but the patterns are not the same for each host system. In boreal host species there are peaks in summer (C. bairdi) or fall (C. opilio), whereas in more temperate species, outbreaks occur primarily in the fall (C. sapidus and possibly $N$. puber) or late winter and spring (N. norvegicus, C. pagurus). Differences in temperature requirements are implicated with these fluctuations in seasonality, but the patterns are not similar between hosts, and therefore indicate likely strain or species differences between parasites. However, one common pattern is apparent. In all of these systems, a nadir occurs when infections are extremely low or even undetectable in host populations. These nadirs in prevalence are suggestive of either a latency of infection or an external reservoir for these parasites. Here again, the role of amphipods or other crustaceans as reservoirs or a resting cyst as a stage in the life cycle cannot be discounted.

\section{Environmental factors}

Several environmental factors affect the epidemiology of Hematodinium. While water temperature cannot be separated easily from seasonality, some studies suggest an effect on the development of infections. In Callinectes sapidus, the intensity of Hematodinium infections increased during warmer temperature, $>15^{\circ} \mathrm{C}$, and decreased at lower temperatures $<16^{\circ} \mathrm{C}$ (Messick et al. 1999). In Nephrops norvegicus, laboratory studies with in vitro cultures indicate that developmental changes in the life cycle proceed above $8^{\circ} \mathrm{C}$, but are retarded when culture temperatures exceed $15^{\circ} \mathrm{C}$ (Appleton \& Vickerman 1998, K. Vickerman pers. comm.).
Salinity is an important factor in the spread of Hematodinium in Callinectes sapidus populations. Hematodinium is endemic in crabs from high salinity waters of the mid-Atlantic and Gulf states (Messick and Shields 2000). The parasite is rarely reported below $18 \mathrm{ppt}$ (Newman \& Johnson 1975, Messick \& Sinderman 1992, Messick \& Shields 2000). With the exception of the work presented by Briggs \& McAliskey (2002), virtually all other infections of Hematodinium have been reported in stenohaline species that experience only minor variations in ambient salinity. Hematodinium infections in Nephrops norvegicus from the Irish Sea showed a significant positive correlation between prevalence and salinity (Briggs \& McAliskey 2002), but the slope of the relation approached zero and was not tested for significance. However, it seems unlikely that salinity would be a significant factor in stenohaline host species as the magnitude of change in salinity in marine zones is relatively minor in comparison with that experienced by euryhaline hosts such as $C$. sapidus in estuarine zones. Changes in the osmotic pressure and electrolytic ions (see above) should be evaluated in relation to the progression and severity of disease in C. sapidus. It is worth speculating that Chatton \& Poisson (1931) may have recorded a higher prevalence for the type host, the euryhaline Carcinus maenas, had they captured them from areas of higher salinity.

\section{‘Landscape' ecology}

Several outbreaks of Hematodinium have distinct associations with physiographic and hydrographic features. Outbreaks in Necora puber and Cancer pagurus fisheries in the English Channel (Latrouite et al. 1988, Wilhelm \& Mialhe 1996) were associated with embayments or partially restricted coastal systems presumably with entrained water masses. Outbreaks in $C$. sapidus have been associated with embayments, shallow backwaters and lagoons (Messick \& Shields 2000). Outbreaks in Chionoecetes opilio and Nephrops norvegicus have been associated with fjords with shallow sills or otherwise constricted areas (Meyers et al. 1987, 1990, Eaton et al. 1991, Field et al. 1992, Field 1998, Stentiford et al. 2001c, Pestal et al. 2003, Shields et al. 2005). However, outbreaks are also known from more open ocean regions (Meyers et al. 1996, Field et al. 1998, Briggs \& McAliskey 2002, Stentiford et al. 2002). Here, depth may facilitate the concentration of infectious stages since female snow crabs from $>250 \mathrm{~m}$ had prevalences almost twice as high as those from shallower areas (Pestal et al. 2003) and infections were rare at depths <200 m (Shields et al. 2005). Habitat or substrate type was important to the parasite in $C$. opilio as 
prevalence was highest in crabs from mud/sand habitats compared to other habitats (Shields et al. 2005). Such habitat restrictions hint again at the presence of alternate hosts or dietary factors. In many of these cases, the enclosed areas had somewhat high-density, 'closed' populations, relatively high potential for entrainment of water, and stressful conditions such as high temperatures, seasonal hypoxia, seasonal fishing, or predation pressure (Shields 1994). In open ocean systems, such as those for C. bairdi and C. opilio populations in the Bering Sea, the prevalences of Hematodinium were variable, with most but not all regions exhibiting low prevalences (Meyers et al. 1996), albeit relationships with habitat type were not explored. Such associations with physiographic and hydrographic features were first noted for rhizocephalan infections in king crabs (Sloan 1984) and have since been noted for nemertean infestations on king crabs (Kuris et al. 1991) as well as for Hematodinium infections. Associating hydrographic features with epidemiology in a marine system can be difficult at best. Methods to study these relationships should be further developed.

\section{Epizootic periodicity}

In addition to seasonal epidemics of Hematodinium, evidence also exists for longer-term cycles of infection. In 1991 and 1992, an epizootic of Hematodinium affected 70 to $100 \%$ of the juvenile Callinectes sapidus in the seaside bays of Maryland and Virginia (Messick 1994). In 1996 and 1997, prevalence ranged from 10 to $40 \%$ in the eastern embayments of the Delmarva Peninsula and 1 to $10 \%$ in the eastern portions of lower Chesapeake Bay (Messick \& Shields 2000). While the evidence is circumstantial, Messick \& Shields (2000) speculated that periodic declines in $C$. sapidus landings that had occurred over 30 yr might have resulted from outbreaks of Hematodinium or from Paramoeba perniciosa, another pathogen in the region (see Newman \& Ward 1973). Evidence from the Scottish fishery for Nephrops norvegicus has shown that prevalence was particularly high during the early 1990s (up to $70 \%$ ) fluctuating at lower levels into the late 1990s, when it peaked at around $40 \%$ (Field et al. 1998, Stentiford et al. 2001c,d). Evidence from the Chionoecetes opilio fishery shows the establishment and catastrophic outbreak of Hematodinium in the northern bays of Newfoundland. Prevalences have increased steadily from $0.037 \%$ to $4.25 \%$ over $10 \mathrm{yr}$ (Pestal et al. 2003) reaching over $9 \%$ of males and $25 \%$ of females in an epizootic occurring in Conception Bay in 2000 (Shields et al. 2005).

\section{Mortality and resistance}

Hematodinium infections are highly pathogenic; thus, it is assumed that they pose a significant mortality risk to their hosts. In laboratory studies, mortality rates of 50 to $100 \%$ over several months have been reported for naturally infected laboratory-held Chionoecetes bairdi (Meyers et al. 1987, Love et al. 1993), C. opilio (Shields et al. 2005), and Nephrops norvegicus (Field et al. 1992). In experimentally infected Callinectes sapidus the disease apparently progresses much faster than that for cold-water species, with a mortality rate of $87 \%$ over 40 d (Shields \& Squyars 2000). Survival analysis indicated that inoculated crabs had a mean time to death of $30 \mathrm{~d}$ and were 7 to 8 times more likely to die than uninfected crabs. Interestingly, during challenge studies, small numbers of blue crabs were refractory to infection; these 'immune' crabs exhibited significant relative and absolute increases in granulocytes, whilst not developing hemocytopenia, a loss of clotting ability, or changes in morbidity (Shields \& Squyars 2000). On several occasions other 'immune' crabs were serially challenged with infectious doses of H. perezi and did not develop infections (J. D. Shields unpubl. data). Such 'immunity' in previously challenged hosts is an interesting phenomenon in light of the fact that mature hosts appear less prone to developing Hematodinium infection compared to their juvenile counterparts (Meyers et al. 1987, Messick 1994). Mortality studies between juveniles and adults and between males and females could prove enlightening.

\section{Fishery assessments}

Given the morbidity and mortality associated with infected crabs and lobsters, it is not surprising to find biases in prevalence between methods used to assess the fisheries. Velvet crabs infected with Hematodinium sp. off France, showed significantly higher prevalences in trawl samples compared to pot samples primarily due to non-selective catching of healthy and diseased crabs (Wilhelm \& Boulo 1988, Wilhelm \& Mialhe 1996). Trawl samples of snow crabs from Newfoundland also showed a higher prevalence in disease than pot samples (Pestal et al. 2003, Shields et al. 2005). However, trawls also had a lower minimum size of retention than traps and prevalence tended to be higher in smaller crabs than in larger crabs (Pestal et al. 2003, Shields et al. 2005). Trawls and underwater video sledges have been used for population assessments of Nephrops norvegicus. Trawled lobsters were used to gauge prevalence and sledges were used to assess temporal changes in burrow density (Field et al. 1998). Epizootics of Hematodinium coincided with stark declines 
( 60 to $75 \%)$ in burrow density that appeared independent of the fishery indicating that the fishery was underestimating the prevalence of the disease in the population. Given the potential for bias in assessment methods, it is essential that estimates of diseased populations be based on unbiased collection methods, such as appropriate trawls or videography, that include all segments of the affected population including prerecruit juveniles.

\section{COMMERCIAL IMPLICATIONS OF INFECTION}

Crustaceans support considerable local, national and regional fisheries with significant demands from global markets. In terms of economic effect, species of Hematodinium have the potential for impact at the level of the population, the fishery and the market. In Alaska, the Chionoecetes bairdi and C. opilio fisheries have suffered localized declines in certain stocks due to Hematodinium infection. This condition is known as 'Bitter Crab Disease' (BCD) or 'Bitter Crab Syndrome' due to the flavour this infection imparts to the flesh (Meyers et al. 1987, 1990). For C. bairdi, the monetary impact was estimated at $\$ 250,000$ or more and was primarily localized to a few impacted fjords in southeastern Alaska (Meyers et al. 1987). More recently, the disease was shown to impact at least one third of the commercial fishery for C. bairdi in southeast Alaska (Meyers et al. 1990). For the C. opilio fishery in Newfoundland, although Taylor \& Khan (1995) reported a low level $(0.037 \%)$ of BCD during the early 1990s with little monetary impact; more recently the prevalence has increased significantly to between $10 \%$ and $26 \%$ in coastal bays causing concern to the industry (Pestal et al. 2003, Shields et al. 2005). Financial implications for these fisheries in the Gulf of Alaska and Bering Sea have not been determined. In Virginia, the Callinectes sapidus fishery undergoes periodic summer and autumn mortalities due to Hematodinium. These mortalities approach $\$ 500000$ to $\$ 1000000$ per year albeit the fishers rarely realize this loss (J. D. Shields unpubl. data). In France, the Necora puber fishery suffered a catastrophic decline (>96\%) due to Hematodinium with a virtual loss of this small fishery (Wilhelm \& Mialhe 1996). Populations of commercially valuable Maia squinado and Cancer pagurus also harbour infections by this parasite, but economic damages have not been calculated (Latrouite et al. 1988, Stentiford et al. 2002). In Scotland, the lucrative Nephrops norvegicus fishery suffered estimated losses of $£ 2$ to 4 million to the Hematodinium parasite in the early 1990s (Field et al. 1992). Since then, this parasite has been responsible for annual seasonal epidemics of varying proportions (between 20 and $70 \%$ prevalence) (Field et al. 1998, Stentiford et al. 2001c).
The real cost of outbreaks of Hematodinium are hard to assess. Background mortalities due to the disease are often difficult to determine because dead hosts quickly become undiagnosable. Further, mortalities occur primarily in juveniles and females and often go unnoticed (Shields 2003, Shields et al. 2005). However, immunological tools for detection of infections in dead crabs can be useful as shown for the detection of sub-patent infections in field-caught animals (Small et al. 2002). Economic analyses of these systems may provide more solid justification for the increased funding to study the problem of Hematodinium in such fisheries.

As with most fisheries, the question arises as to why be concerned about diseases when nothing can be done to limit their effects on the fished population. As described above, background Hematodinium prevalence can reach 70 to $100 \%$ during outbreaks where mortalities to the pre-recruit and adult populations can approach 100\% (Messick 1994, Shields \& Squyars 2000, Shields 2003, Shields \& Overstreet 2004). Few if any fisheries models make use of disease data (prevalence, distribution) to estimate effects or otherwise manage a fishery. The development of spatial models for systems with disease has great potential because such models can incorporate biological data and integrate it over different spatial scales. With such models, 'at risk' populations can be identified, especially where the structure (e.g. sex or sized biased) of that population makes it susceptible to epizootics.

\section{Controlling disease}

Anecdotal evidence suggests that some fishing practices may help to spread diseases. Such practices include the culling or disassembly of the catch at sea, re-baiting with infected animals, moving animals between locations (culling while underway), and in some cases using crabs as 'attractants' to bait for additional animals (e.g. using male Callinectes sapidus to attract premoult females for the softshell industry) (Shields 2003, Shields \& Overstreet 2004). These practices will contribute to the spread of disease to new locations. By understanding transmission and pathogenicity of a disease, the effect of such practices can be curtailed or minimized. Control strategies include culling on station or within a watershed, culling or removing dead animals to onshore fertilizer processing plants, limiting transportation of live animals, and changing baiting practices. Efforts to notify fishers of these measures have been implemented in the Chionoecetes opilio fishery of Newfoundland (D. Taylor, pers. comm.). 
Changes in fishing policies may also be warranted. Some evidence from the Nephrops norvegicus fishery in Scotland suggests that the population structure of a given fishery is related to the prevalence of Hematodinium infection within that fishery, with populations of small, size-matched individuals having the highest prevalence (Stentiford et al. 2001c). As such, fisheries management regimes to promote normal size distributions within the fishery have potential for averting epizootics. Whether such relationships exist for Hematodinium infection prevalence in crab fisheries remains to be shown. With outreach or other education programs, fishermen, wholesalers and processors could gain an improved understanding of the infectious agent responsible for the disease and could therefore assist with the control of its spread. In the case of southeast Alaskan Chionoecetes bairdi populations, the seasonal nature of infection may be exploited to exercise some control over high prevalences. Newly infected crabs could be harvested prior to the development of patent infections thereby reducing the necessity to cull heavily infected crabs later in the season. The reduced dissemination of infected carcasses would also follow (Meyers et al. 1987, 1990). However, determining early infections would require shipboard diagnosis. Finally, with the advent of live shipping of crabs and lobsters to distant markets, there is an increased potential for the inadvertent introduction of pathogenic agents to new regions. Similar events have created problems for the shrimp culture industry (Flegel 1997, Lightner \& Redman 1998) and have marginalized the abalone industry in California in the 1990s (Oakes \& Fields 1996, Ruck \& Cook 1998).

\section{Commercial products}

As Hematodinium infections alter the appearance of the product or by causing an unpalatable flavour, as is the case for bitter crab disease in Chionoecetes opilio and $C$. bairdi, small numbers of diseased crab can render an entire batch of crabs unpalatable if batch processed (Meyers et al. 1987, Taylor \& Khan 1995). Severe departures occur in the biochemical profiles of muscle and hepatopancreatic tissues from Hematodinium-infected Nephrops norvegicus (Stentiford et al. 1999, 2000b). Such changes will contribute to flavour changes in this and other infected hosts. No dedicated studies have examined the organoleptic or mechanical changes to the meat products harvested from animals bearing patent Hematodinium infections.

Finally, despite its significant impact on fisheries and marketing, to the best of our knowledge, comprehensive studies to assess the potential human health impact of consuming Hematodinium-infected crusta- ceans have not occurred. Chitin-associated asthma is a risk factor for workers processing snow and tanner crab for market (Smith \& Sechena 1996) but, at this time, the connection between Hematodinium spp. and asthma or other health-related effects remains purely speculative.

\section{FUTURE DIRECTIONS}

The commercial and ecological significance of these parasites is based upon their ability to impact the size and structure of important host populations and to alter the meat harvested from commercial species. To date, limited efforts have been directed towards defining the taxonomic status of this group and we see this as a key objective for future studies. Re-discovery and a full ultrastructural and molecular description of the type species, Hematodinium perezi, from the type hosts collected at the type location should be coupled with an in vitro (and if possible, in vivo) life-cycle study of the isolate. This information would allow for a comparative analysis of other Hematodinium species described from crustacean hosts in Europe, the United States and Australia.

There are also considerable gaps in our knowledge concerning the route of transmission, developmental periods, reservoir hosts, and species specificity of individual isolates of this parasitic group. Further study in these areas should strive to relate findings to population-based studies and particularly to the effect of the behaviour of fishers on the perpetuation of this disease in certain commercial and non-commercial stocks. Information pertaining to these studies can then be used to make informed decisions for management change to assist in the control of epizootics in wild stocks. For example, we could envision a markrecapture study of discards in the Chionoecetes opilio or $C$. bairdi fisheries that might address the spread of disease, the natural mortality of infected crabs, or the elevation of prevalence by fishing pressure.

Finally, the commercial impact of Hematodinium infections must be given further attention. We have described how these infections have negatively affected a number of commercial crustacean fisheries in the United States and in Europe. However, to date, no definitive studies have modelled the impact of disease at the population level or on the status of the products harvested from these fisheries.

Acknowledgements. We thank H. Small (VIMS), D. Taylor (DFO Newfoundland) and S. Feist (CEFAS) for their critical comments and access to their unpublished data. This is VIMS Contribution 2628. United Kingdom Crown copyright retained. 


\section{LITERATURE CITED}

Alexander SK (1986) Diet of the blue crab, Callinectes sapidus Rathbun, from nearshore habitats of Galveston Island, Texas. Texas J Sci 38:85-89

Appleton PL, Vickerman K (1996) Presence of Apicomplexantype micropores in a parasitic dinoflagellate, Hematodinium sp. Parasitol Res 82:279-282

Appleton PL, Vickerman K (1998) In vitro cultivation and development cycle in culture of a parasitic dinoflagellate (Hematodinium sp.) associated with mortality of the Norway lobster (Nephrops norvegicus) in British waters. Parasitology 116:115-130

Audemard C, Le Roux F, Cousteau C, Barnaud A and 6 others (2002) Needle in a haystack: involvement of the copepod Paracartia grani in the lifecycle of the oyster pathogen Marteilia refringens. Parasitology 124:315-323

Bang FB (1983) Crustacean disease responses. In: Provenzano AJ Jr (ed) The biology of crustacea, Vol 6, Pathobiology. Academic Press, New York, p 113-153

Bauchau AG (1981) Crustaceans. In: Ratcliffe NA Rowley AF (eds) Invertebrate blood cells, Vol 2, arthropods to urochordates, invertebrates and vertebrates compared. Academic Press, London, p 386-420

Bauchau AG, DeBrouwer MB (1972) Etude ultrastructurale de la coagulation de l'hémolymph chez les crustacés. J Microscopy 15:171-180

Bower SM, Meyer GR (2002) Morphology and ultrastructure of a protistan pathogen in the haemolymph of shrimp (Pandalus spp.) in the northeastern Pacific Ocean. Can J Zool 80:1055-1068

Bower SM, Meyer GR, Boutillier JA (1993) Diseases of spot prawns Pandalus platyceros caused by an intracellular bacterium and a Hematodinium-like protozoa. J Shellfish Res 12:135

Bower SM, Meyer GR, Phillips A, Workman G, Clark D (2003) New host and range extension of bitter crab syndrome in Chionoecetes spp. caused by Hematodinium sp. Bull Eur Assoc Fish Pathol 23:86-91

Briggs RP, McAliskey M, (2002) The prevalence of Hematodinium in Nephrops norvegicus from the western Irish Sea. J Mar Biol Assoc UK 82:427-433

Cachon J, Cachon M (1987) Parasitic dinoflagellates. In: Taylor FJR (ed) The biology of dinoflagellates. Blackwell Scientific Publications, p 571-610

Cavalier-Smith T (1993) Kingdom Protozoa and its 18 phyla. Microbiol Rev 57:953-994

Chatton E (1920) Les Péridiniens parasites: morphologie, reproduction, ethologie. Arch Zool Exp Gen 59:1-475

Chatton E (1952) Classe des Dinoflagelles ou Péridiniens. In: Grassé P -P (ed); Traité de Zoologie, Vol 1. Masson et Cie, Paris, p 309-390

Chatton E, Poisson, R (1931) Sur l'existence, dans le sang des crabs, de peridiniens parasites: Hematodinium perezi n.g., n.sp. (Syndinidae). CR Sceances Soc Biol Paris 105: 553-557

Chung JS, Dircksen H, Webster SG (1999) A remarkable, precisely timed release of hyperglycemic hormone from endocrine cells in the gut is associated with ecdysis in the crab Carcinus maenas. Proc Natl Acad Sci USA 96: 13103-13107

Coats DW (1999) Parasitic lifestyles of marine dinoflagellates. J Eukaryot Microbiol 46:402-409

Dawe E (2002) Trends in the prevalence of bitter crab disease caused by Hematodiniun sp. in snow crab (Chionoecetes opilio) through out the Newfoundland and Labrador continental shelf. In: Crabs in cold water regions: biology, man- agement, and economics. Alaska Sea Grant Report AK-SG-02-01, Alaska Sea Grant Program, University of Alaska, Fairbanks, AK, p 385-400

Durliat M (1989) Coagulation in Crustacea. In: Gupta AP (ed) Immunology of insects and other arthropods. CRC Press, Boca Raton, FL, p 239-272

Eaton WD, Love DC, Botelho C, Meyers TR, Imamura K, Koeneman T (1991) Preliminary results on the seasonality and life cycle of the parasitic dinoflagellate causing Bitter Crab Disease in Alaskan Tanner crabs (Chionoecetes bairdi). J Invertebr Pathol 57:426-434

Field RH, Appleton PL (1995) A Hematodinium-like infection of the Norway lobster Nephrops norvegicus: observations on pathology and progression of infection. Dis Aquat Org 22:115-128

Field RH, Appleton PL (1996) An indirect fluorescent antibody technique for the diagnosis of Hematodinium sp. infection of the Norway lobster Nephrops norvegicus. Dis Aquat Org 24:199-204

Field RH, Chapman CJ, Taylor AC, Neil DM, Vickerman K (1992) Infection of the Norway lobster Nephrops norvegicus by a Hematodinium-like species of dinoflagellate on the west coast of Scotland. Dis Aquat Org 13:1-15

Field RH, Hills JM, Atkinson RJA, Magill S, Shanks AM (1998) Distribution and seasonal prevalence of Hematodinium sp. infection of the Norway lobster (Nephrops norvegicus) around the west coast of Scotland. ICES J Mar Sci 55:846-858

Flegel TW (1997) Major viral diseases of the black tiger prawn (Penaeus monodon) in Thailand. World J Microbiol Biotechnol 13:433-442

Gajadhar AA, Marquardt WC, Hall R, Gunderson J, AriztiaCarmona EV, Sogin ML (1991) Ribosomal RNA sequences of Sarcocystis muris, Theileria annulata and Crypthecodinium cohnii reveal evolutionary relationships among apicomplexans, dinoflagellates, and ciliates. Mol Biochem Parasitol 45:147-154.

Ghidalia W, Vendrely R, Montmory C, Coirault Y, Samama M, Lucet B, Bellay AM, Vergoz D (1981) Coagulation in decapod Crustacea: a comparative study of the clotting process in species from groups A, B and C. J Comp Physiol 142: 473-478

Gruebl T, Frischer ME, Sheppard M, Neumann M, Maurer AN, Lee RF (2002) Development of an 18S rRNA genetargeted PCR based diagnostic for the blue crab parasite Hematodinium sp. Dis Aquat Org 49:61-70

Hallegraeff GM (1993) A review of harmful algal blooms and their apparent global increase. Phycologia 32:79-93

Hervio D, Chagot D, Godin P, Grizel H, Miahle E (1991) Localization and characterization of acid phosphatase activity in Bonamia ostrea (Ascetospora), an intrahemocytic protozoan parasite of the flat oyster Ostrea edulis (Bivalvia) Dis Aquat Org 12:67-70

Hillis JP, Tully O (1993) Growth rate, mortality and small mean size in Irish Sea Nephrops. ICES Council Meeting Papers, Copenhagen

Hose JE, Martin GG, Gerard AS (1990) A decapod classification scheme integrating morphology, cytochemistry and function. Biol Bull (Woods Hole) 178:33-45

Hudson D, Hudson N, Shields, JD (1993) Infection of Trapezia spp. (Decapoda: Xanthidae) by Hematodinium sp. (Duboscquodinida: Syndinidae): a new family record of infection. J Fish Dis 16:273-276

Hudson DA (1995) Biochemical parameters of the serum of the sand crab, Portunus pelagicus, with reference to the parasitic dinoflagellate, Hematodinium australis. Bull Eur Assoc Fish Pathol 15:202-205 
Hudson DA, Adlard RD (1994) PCR-techniques applied to Hematodinium spp and Hematodinium-like dinoflagellates in decapod crustaceans. Dis Aquat Org 20:203-206

Hudson DA, Adlard RD (1996) Nucleotide sequence determination of the partial SSU rDNA gene and ITS1 region of Hematodinium cf. perezi and Hematodinium-like dinoflagellates. Dis Aquat Org 24:55-60

Hudson DA, Lester RJG (1994). Parasites and symbionts of wild mud crabs Scylla serrata (Forskal) of potential significance in aquaculture. Aquaculture 120:183-199.

Hudson DA, Shields JD (1994) Hematodinium australis n. sp., a parasitic dinoflagellate of the sand crab Portunus pelagicus from Moreton Bay, Australia. Dis Aquat Org 19: 109-119

Ismail SO, Paramchuk W, Skeiky YAW, Reed SG, Bhatia A, Gedamu L (1997) Molecular cloning and characterization of two iron superoxide dismutase cDNAs from Trypanosoma cruzi. Mol Biochem Parasitol 86:187-197

Johnson PT (1976) Bacterial infection in the blue crab, Callinectes sapidus: course of infection and histopathology. J Invertebr Pathol 28:25-36

Johnson PT (1980) Histology of the blue crab, Callinectes sapidus: Course of infection and histopathology. Praeger Publishers, New York

Johnson PT (1983) Diseases caused by viruses, rickettsiae, bacteria, and fungi. In: Provenzano AJ (ed) The biology of crustacea, Vol 6. Pathology. Academic Press, New York, p 1-78

Johnson PT (1986) Parasites of benthic amphipods: dinoflagellates (Duboscquodinida: Syndinidae). Fish Bull US 84: 605-614

Katakura K (1986) Studies on infectivity of Leishmania donovani promastigotes: isolation, intracellular behavior and biological characteristics of virulent lines. Jikeikai Med J 33:157-173

Katakura K, Kobayashi A (1988) Acid phosphatase activity of virulent and avirulent clones of Leishmania donovani promastigotes. Infect Immun 56:2856-2860

Kummer G, Keller R (1993) High-affinity binding of crustacean hyperglycemic hormone $(\mathrm{CHH})$ to hepatopancreatic plasma membranes of the crab, Carcinus maenas and the crayfish, Orconectes limosus. Peptides 14:103-108

Kuris AM, Blau SF, Paul AJ, Shields JD, Wickham DE (1991) Infestation by brood symbionts and their impact on egg mortality in the red king crab, Paralithodes camtschatica, in Alaska: Geographic and temporal variation. Can J Fish Aquat Sci 48:559-568.

Latrouite D, Morizur Y, Noël P, Chagot D, Wilhelm G (1988) Mortalite du tourteau Cancer pagurus provoquee par le dinoflagellate parasite: Hematodinium sp. Cons Int Explor Mer, CM 1988/K: 32

Laughlin RA (1982) Feeding habits of the blue crab, Callinectes sapidus Rathbun, in the Apalachicola Estuary, Florida. Bull Mar Sci 32:807-822

Lightner DV, Redman RM (1998) Strategies for the control of viral diseases of shrimp in the Americas. Fish Path 33: 165-180

Love D, Thomas R, Moles A (1996) Bitter Crab hemolymph studies: indications of host physiological condition. Alaska Sea Grant Report AK-SG-02-01, Alaska Sea Grant Program, University of Alaska, Fairbanks, AK

Love DC, Rice SD, Moles DA, Eaton WD (1993) Seasonal prevalence and intensity of Bitter Crab dinoflagellate infection and host mortality in Alaskan Tanner crabs Chionoecetes bairdi from Auke Bay, Alaska, USA. Dis Aquat Org 15:1-7

Lovrich GA, Sainte-Marie B (1997) Cannibalism in the snow crab, Chionoecetes opilio (O. Fabricius) (Brachyura: Majidae), and its potential importance to recruitment. J Exp Mar Biol Ecol 211:225-245

MacLean SA, Ruddell CL (1978) Three new crustacean hosts for the parasitic dinoflagellate Hematodinium perezi (Dinoflagellata: Syndinidae). J Parasitol 64:158-160

Manier J.-F, Fize A, Grizel H (1971) Syndinium gammari n. sp. péridinien Dubosquodinida Syndinidae, parasite de Gammarus locusta (Lin.) Crustacè Amphipode. Protistologica 7:213-219

Martin GG, Hose JE, Omori S, Chong C, Hoodbhoy T, McKrell N (1991) Localization and roles of coagulogen and transglutaminase in hemolymph coagulation in decapod crustaceans. Comp Biochem Physiol 100B: 517-522

Messick GA (1994) Hematodinium perezi infections in adult and juvenile blue crabs Callinectes sapidus from coastal bays of Maryland and Virginia, USA. Dis Aquat Org 19: 77-82

Messick GA, Shields JD (2000) Epizootiology of the parasitic dinoflagellate Hematodinium sp. in the American blue crab Callinectes sapidus. Dis Aquat Org 43:139-152

Messick GA, Jordan SJ, Van Heukelem WF (1999) Salinity and temperature effects on Hematodinium sp. in the blue crab Callinectes sapidus. J Shell Res 18:657-662

Meyers TR, Koeneman TM, Bothelho C, Short S (1987) Bitter Crab Disease: a fatal dinoflagellate infection and marketing problem for Alaskan Tanner crabs Chionoecetes bairdii. Dis Aquat Org 3:195-216

Meyers TR, Botelho C, Koeneman TM, Short S, Imamura K (1990) Distribution of bitter crab dinoflagellate syndrome in southeast Alaskan tanner crabs, Chionoecetes bairdi. Dis Aquat Org 9:37-43

Meyers TR, Lightner DV, Redman RM (1994) A dinoflagellate-like parasite in Alaskan spot shrimp Pandalus platyceros and pink shrimp P. borealis. Dis Aquat Org 18:71-76

Meyers TR, Morado JF, Sparks AK, Bishop GH, Pearson T, Urban D, Jackson D (1996) Distribution of bitter crab syndrome in tanner crabs (Chionoecetes bairdi, C. opilio) from the Gulf of Alaska and the Bering Sea. Dis Aquat Org 26:221-227

Moksnes P-O, Lipcius RN, Pihl L, Van Montfrans J (1997) Cannibal-prey dynamics in young juveniles and postlarvae of the blue crab. J Exp Mar Biol Ecol 215:157-187

Morado JF, Small EB (1994) Morphology and stomatogenesis of Mesanophrys pugettensis n. sp. (Scuticociliatida: Orchitophryidae), a facultative parasitic ciliate of the Dungeness crab, Cancer magister (Crustacea: Decapoda). Trans Am Microsc Soc 113:343-364

Newman MW (1970) A possible neoplastic blood disease of blue crabs. In: Dutcher RM (ed) Comparative leukemia research, Bibl. Haemat. \#36. Karger, Basel

Newman MW, Johnson CA (1975) A disease of blue crabs (Callinectes sapidus) caused by a parasitic dinoflagellate, Hematodinium sp. J Parasitol 63:554-557

Newman MW, Ward GE Jr (1973) An epizootic of blue crabs, Callinectes sapidus, caused by Paramoeba perniciosa. J Invertebr Pathol 22:329-334

Oakes FR, Fields RC (1996) Infestation of Haliotis rufescens shells by a sabellid polychaete. Aquaculture 140:139-143

Paramchuk WJ, Ismail SO, Bhatia A, Gedamu L (1997) Cloning, characterization and overexpression oftwo iron superoxide dismutase cDNAs from Leishmania chagasi: role in pathenogenesis. Mol Biochem Parasitol 90:203-221

Pauley GB, Newman MW, Gould E (1975) Serum changes in the blue crab, Callinectes sapidus, associated with Paramoeba perniciosa, the causative agent of gray crab disease. Mar Fish Rev 37:34-38 
Pestal GP, Taylor DM, Hoenig JM, Shields JD, Pickavance R (2003) Monitoring the presence of the lethal parasite Hematodinium sp. in snow crabs from Newfoundland. Dis Aquat Org 53:67-75

Reece KS, Burreson EM, Bower SM, Dungan CF (2000) Molecular analyses of a parasite in prawns (Pandalus platyceros) from British Columbia, Canada. J Shellfish Res 19: 647

Ris H, Kublai DF (1974) An unusual mitotic mechanism in the parasitic protozoan Syndinium sp. J Cell Biol 60:702-720

Ruck KR, Cook PA (1998) Sabellid infestations in the shells of South African molluscs: Implications for abalone mariculture. J Shellfish Res 17:693-699.

Santos EA, Keller R (1993) Regulation of circulating levels of crustacean hyperglycaemic hormone: evidence for a dual feedback control system. J Comp Physiol B 163:374-379

Santos EA, Stefanello TM (1991) The hemolymph of Chasmagnathus granulata Dana, 1851 (Decapoda - Grapsidae) as a target tissue of the crustacean hyperglycemic hormone. Braz J Med Biol Res 24:267-270

Sheppard M, Walker A, Frischer ME, Lee RF (2003) Histopathology and prevalence of the parasitic dinoflagellate Hematodinium sp, in crabs (Callinectes sapidus, Callinectes similis, Neopanope sayi, Libinia emarginata, Menippe mercenaria) from a Georgia estuary. J Shellfish Res 22: 873-880

Shields JD (1992) Parasites and symbionts of the crab Portunus pelagicus from Moreton Bay, eastern Australia. J Crustac Biol 12:94-100

Shields JD (1994) The parasitic dinoflagellates of marine crustaceans. Annu Rev Fish Dis 4:241-271

Shields JD (2003) Research priorities for diseases of the blue crab Callinectes sapidus. Bull Mar Sci 72:505-517

Shields JD, Overstreet RM (2004). Parasites, symbionts, and diseases. In: Kennedy V (ed) The biology and management of the blue crab. University of Maryland Sea Grant Press, MD

Shields JD, Squyars CM (2000) Mortality and hematology of blue crabs, Callinectes sapidus, experimentally infected with the parasitic dinoflagellate Hematodinium perezi. Fish Bull 98:139-152

Shields JD, Scanlon C, Volety A (2003) Aspects of the pathophysiology of blue crabs, Callinectes sapidus, infected with the parasitic dinoflagellate Hematodinium perezi. Bull Mar Sci 72:519-535

Shields JD, Taylor DM, Sutton SG, O'Keefe PO, Collins PW, Ings DW, Pardy AL (2005) Epizootiology of bitter crab disease (Hematodinium sp.) in snow crabs, Chionoecetes opilio, from Newfoundland, Canada. Dis Aquat Org 64: 253-264

Singala N, Kuller GK, Vinayak VK (1992) Acid phosphatase activity of promastigotes of Leishmania donovani: a marker of virulence. FEMS Microbiol Lett 94:221-226

Sloan NA (1984) Incidence and effects of parasitism by the rhizocephalan barnacle, Briarosaccus callosus Boschma, in the golden king crab, Lithodes aequispina Benedict, from deep fjords in northern British Columbia, Canada. J Exp Mar Biol 84:111-131

Small HJ (2004) Infections of the Norway lobster Nephrops norvegicus (L.) by dinoflagellate and ciliate parasites. PhD Thesis, University of Glasgow

Small HJ, Wilson S, Neil DM, Hagan P, Coombs GH (2002) Detection of the parasitic dinoflagellate Hematodinium in the Norway lobster Nephrops norvegicus by ELISA. Dis Aquat Org 52:175-177

Smayda TJ (1997) Bloom dynamics: physiology, behavior, trophic effects. Limnol Oceanogr 42:1132-1136
Smith DD, Sechena R (1996) Arctic snow crab-related lung disease. Int J Circumpolar Health 57:601-608

Smith VJ, Chisholm JRS (1992) Non-cellular immunity in crustaceans. Fish Shellfish Immunol 2:1-31

Smith VJ, Söderhäll K (1986) Cellular immune mechanisms in the Crustacea. Symp Zool Soc Lond 56:59-79

Squires HJ, Dawe EG (2003) Stomach contents of snow crab (Chionoecetes opilio), Decapoda, Brachyura) from the northeast Newfoundland shelf. J Northw Atl Fish Sci 32: $27-38$

Stentiford GD, Neil DM, Coombs GH (1999) Changes in the plasma free amino acid profile of the Norway lobster Nephrops norvegicus at different stages of infection by a parasitic dinoflagellate (genus Hematodinium). Dis Aquat Org 38:151-157

Stentiford GD, Neil DM, Atkinson RJA, Bailey N (2000a) An analysis of swimming performance in the Norway lobster, Nephrops norvegicus L. infected by a parasitic dinoflagellate of the genus Hematodinium. J Exp Mar Biol Ecol 247: 169-18

Stentiford GD, Neil DM, Coombs GH (2000b) Alterations in the biochemistry and ultrastructure of the deep abdominal flexor muscle of the Norway lobster, Nephrops norvegicus L. during infection by a parasitic dinoflagellate of the genus Hematodinium. Dis Aquat Org 42:133-141

Stentiford GD, Chang ES, Chang SA, Neil DM (2001a) Carbohydrate dynamics and the crustacean hyperglycaemic hormone $(\mathrm{CHH})$ : effects of parasitic infection in Norway lobsters (Nephrops norvegicus). Gen Comp Endocrinol 121:13-22

Stentiford GD, Neil DM, Atkinson RJA (2001b) Alteration of burrow-related behaviour of the Norway lobster, Nephrops norvegicus during infection by the parasitic dinoflagellate Hematodinium. Mar Freshw Behav Physiol 34:139-156

Stentiford GD, Neil DM, Atkinson RJA (2001c) The relationship of Hematodinium infection prevalence in a Scottish Nephrops norvegicus population to seasonality, moulting and sex. ICES J Mar Sci 58:814-823

Stentiford GD, Neil DM, Coombs GH (2001d) Development and application of an immunoassay diagnostic technique for studying Hematodinium infections in Nephrops norvegicus populations. Dis Aquat Org 46:223-229

Stentiford GD, Green M, Bateman K, Small HJ, Neil DM, Feist SW (2002) Infection by a Hematodinium-like parasitic dinoflagellate causes Pink Crab Disease (PCD) in the edible crab Cancer pagurus. J Invertebr Pathol 79: 179-191

Stentiford GD, Evans MG, Bateman K, Feist SW (2003) Coinfection by a yeast-like organism in Hematodiniuminfected European edible crabs Cancer pagurus and velvet swimming crabs Necora puber from the English Channel. Dis Aquat Org 54:195-202

Stevenson JR (1985) Dynamics of the integument. In: Bliss DE, Mantel LH (eds) The biology of the crustacea, Vol 9, integument, pigments, and hormonal processes. Academic Press, Orlando, FL, p 1-42

Stewart JE, Zwicker BM, Arie B, Horner GW (1972) Food and starvation as factors affecting the time to death of the lobster Homarus americanus infected with Gaffkya homari. J Fish Res Board Can 29:461-464

Tärnlund S (2000) A comparison of two methods for identifying and assessing the parasitic dinoflagellate Hematodinium sp. in Norway lobster (Nephrops norvegicus). MSc thesis, University of Götenborg

Taylor AC, Field RH, Parslow-Williams PJ (1996) The effects of Hematodinium sp.-infection on aspects of the respira- 
tory physiology of the Norway lobster, Nephrops norvegicus (L.). J Exp Mar Biol Ecol 207:217-228

Taylor DM, Khan RA (1995) Observations on the occurrence of Hematodinium sp. (Dinoflagellata: Syndinidae): the causative agent of Bitter Crab Disease in the Newfoundland snow crab (Chionoecetes opilio). J Invertebr Pathol 65:283-288

Thörnqvist P-O, Söderhäll K (1997) Crustacean immune reactions, a short review. In: Flegel TW, MacRae IH (eds) Diseases in Asian aquaculture III. Fish Health Section, Asian Fisheries Society, Manila, p 203-218

Tuck ID, Atkinson RJA, Chapman CJ (2000) Population biology of the Norway lobster, Nephrops norvegicus ( L.) in the Firth of Clyde, Scotland II: Fecundity and size at onset of sexual maturity. ICES J Mar Sci 57:1227-1239

Uglow RF (1969a) Haemolymph protein concentrations in portunid crabs. I. Studies on adult Carcinus maenas. Comp Biochem Physiol 30:1083-1090

Uglow RF (1969b) Haemolymph protein concentrations in portunid crabs. II. The effects of imposed fasting on Carcinus maenas. Comp Biochem Physiol 31:959-967

Editorial responsibility: Timothy Flegel,

Bangkok, Thailand
Vannier-Santos MA, Martiny A, Meyer-Fernandes JR, de Souza W (1995) Leishmanial protein kinase C modulates host cell infection via secreted acid phosphatase. Eur J Cell Biol 67:112-119

Volety AK, Chu F-L (1997) Acid phosphatase activity in Perkinsus marinus, the protistan parasite of the American oyster, Crassostrea virginica. J Parasitol 83: 1093-1098

Weise M (1998) A mitogen-activated protein (MAP) kinase homologue of Leishmania mexicana is essential for parasite survival in the infected host. EMBO J 17:2619-2628

Wieczorek SK, Hooper RG (1995) Relationship between diet and food availability in the snow crab, Chionoecetes opilio (O. Fabricius) in Bonne Bay, Newfoundland. J Crustac Biol 15:236-247

Wilhelm G, Boulo V (1988) Infection de l'etrille Liocarcinus puber (L.) par un dinoflagellate parasite: Hematodinium sp. Cons Int Explor Mer Ser CM, K: 32(E):1-10

Wilhelm G, Mialhe E (1996) Dinoflagellate infection associated with the decline of Necora puber crab populations in France. Dis Aquat Org 26:213-219

Submitted: July 27, 2004; Accepted: February 11, 2005

Proofs received from author(s): July 12, 2005 